\title{
Characterization and Sources of Aromatic Hydrocarbons (BTEX) in the Atmosphere of Two Urban Sites Located in Yucatan Peninsula in Mexico
}

\author{
Julia Griselda Cerón Bretón ${ }^{1}$ * , Rosa María Cerón Bretón ${ }^{1}$, Francisco Vivas Ucan ${ }^{2}$, \\ Cynthia Barceló Baeza ${ }^{2}$, María de la Luz Espinosa Fuentes ${ }^{3}$, Evangelina Ramírez Lara ${ }^{4}$, \\ Marcela Rangel Marrón ${ }^{1}$, Jorge Alfredo Montero Pacheco ${ }^{1}$, Abril Rodríguez Guzmán ${ }^{1}$ \\ and Martha Patricia Uc Chi ${ }^{1}$ \\ 1 Facultad de Química, Universidad Autónoma del Carmen, Calle 56 Num. 4, 24180 Ciudad del Carmen, \\ Campeche, Mexico; rceron@pampano.unacar.mx (R.M.C.B.); mrangel@pampano.unacar.mx (M.R.M.); \\ jmontero_93@outlook.com (J.A.M.P.); abrilrg708@gmail.com (A.R.G.); marthaucchi@gmail.com (M.P.U.C.) \\ 2 Departamento de Calidad del Aire, Secretaría de Desarrollo Urbano y Medio Ambiente, \\ Gobierno del Estado de Yucatan, Calle 64 No. 437 x 53 y 47-A, 97219 Mérida, Yucatán, Mexico; \\ francisco.vivas@yucatan.gob.mx (F.V.U.); cynthia.barcelo@yucatan.gob.mx (C.B.B.) \\ 3 Centro de Ciencias de la Atmosfera, Universidad Nacional Autónoma de Mexico, Circuito Exterior s/n, \\ Coyoacan, Ciudad Universitaria, 04510 Ciudad de Mexico, Mexico; marilu@atmosfera.unam.mx \\ 4 Facultad de Ciencias Quimicas, Universidad Autónoma de Nuevo León, Av. Universidad s/n, \\ 66451 San Nicolás de las Garza, Nuevo León, Mexico; evangelina.ramirez.lr@gmail.com \\ * Correspondence: jceronbreton@gmail.com; Tel.: +52-272-120-3456
}

Received: 7 May 2017; Accepted: 14 June 2017; Published: 17 June 2017

\begin{abstract}
Benzene, toluene, ethylbenzene, $p$-xylene, $\mathrm{O}_{3}, \mathrm{NO}_{\mathrm{x}}, \mathrm{CO}, \mathrm{PM}_{2.5}$ and meteorological parameters were measured in urban air of two sites in Merida, Yucatan, Mexico during 2016-2017. Samples were collected using $1.5 \mathrm{~h}$ time intervals at three different sampling periods before being analyzed by gas chromatography with flame ionization detection. The highest concentrations of BTEX occurred during midday and afternoon in spring and summer seasons. Mean concentrations of, BTEX for the Cholul and SEDUMA sites, respectively, were $40.91 \mu \mathrm{g} / \mathrm{m}^{3}$ and $32.86 \mu \mathrm{g} / \mathrm{m}^{3}$ for benzene; $6.87 \mu \mathrm{g} / \mathrm{m}^{3}$ and $3.29 \mu \mathrm{g} / \mathrm{m}^{3}$ for toluene; $13.87 \mu \mathrm{g} / \mathrm{m}^{3}$ and $8.29 \mu \mathrm{g} / \mathrm{m}^{3}$ for $p$-xylene; and $6.23 \mu \mathrm{g} / \mathrm{m}^{3}$ and $4.48 \mu \mathrm{g} / \mathrm{m}^{3}$ for ethylbenzene. The toluene/benzene and xylene/ethylbenzene concentration ratios indicated that BTEX levels at both sites were influenced by local and fresh emissions (vehicular traffic). Bivariate and multivariate analyses were performed in order to correlate BTEX concentrations with criteria air pollutants to infer their possible sources. Health risk assessment revealed that exposure to benzene exceeded the recommended value for the integrated lifetime cancer risk. These results suggest that Merida's population is exposed to cancer risk, and changes in the existing environmental policies should therefore be applied to improve air quality.
\end{abstract}

Keywords: volatile organic compounds; BTEX; tropospheric ozone; Merida; air pollution

\section{Introduction}

In recent years, air quality has been the focus of attention due to its degradation in urban areas where air quality is very far from the recommended satisfactory threshold set by the World Health Organization, thereby resulting in a growing need to reduce the levels of toxic pollutants in ambient air [1]. Volatile organic compounds (VOCs) are the most common species present in urban air, being aromatic hydrocarbons derived from benzene (BTEX), a sub-group of this family of compounds. The importance of VOCs in the lower atmosphere is that they are precursors of ozone, some of them are toxic to humans, and they have multiple and different sources [2]. 
The natural cycle of formation and destruction of $\mathrm{O}_{3}$ begins with the action of solar radiation on the nitrogen dioxide molecule $\left(\mathrm{NO}_{2}\right)$, which undergoes photolysis and produces nitrogen monoxide $(\mathrm{NO})$ and atomic oxygen $(\mathrm{O})$. Atomic oxygen reacts with molecular oxygen to form tropospheric ozone $\left(\mathrm{O}_{3}\right)$, which in turn reacts with $\mathrm{NO}$ to form new $\mathrm{NO}_{2}$ and $\mathrm{O}_{2}$, keeping the concentrations of reagents and products in equilibrium [3]. However, this cycle changes in the presence of VOCs. Since they react to form radicals, which either consume $\mathrm{NO}$ or convert $\mathrm{NO}$ to $\mathrm{NO}_{2}$, part of the $\mathrm{O}_{3}$ does not react and accumulates in the atmosphere [4]. It is important to mention that the production of $\mathrm{O}_{3}$ does not show a linear relation with the emission of its precursors, so the $\mathrm{O}_{3}$ response to changes in the concentrations of its precursors is extremely complex and variable. To reduce $\mathrm{O}_{3}$ concentrations, it is necessary to control the emissions of its precursors, nitrogen oxides $\left(\mathrm{NO}_{\mathrm{x}}\right)$ and VOCs, a difficult task because of current lifestyles, such as an excessive use of the automobile in urban areas. According to the Mexican Emissions Inventory [5], automobiles are the main source of $\mathrm{NO}_{\mathrm{x}}(45.67 \%)$. In the case of VOCs, there is a greater number of sources, including exhaust emissions, evaporative emissions in fuel storage and from gas distribution stations, ink printing processes, engine cleaning processes, asphalting streets and dry cleaning, among others. The main sources contributing in Mexico to VOC emissions are regional sources and mobile sources [5]. The content of aromatic hydrocarbons in gasoline-better known as BTEX (benzene, toluene, ethylbenzene and xylenes)—is usually $25 \%$ to $30 \%[6,7]$.

BTEX have been recognized as toxic air pollutants [8-10]. The USA Environmental Protection Agency (EPA) and International Agency for Research on Cancer (IARC) consider benzene as a carcinogenic agent group 1 , which means that there is sufficient scientific evidence to consider a positive relationship between exposure to this toxin and a potential development of cancer in humans and some animals [11,12]. On the other hand, the toxicity of organic solvents and aromatic hydrocarbons (toluene, ethylbenzene, xylenes) has been widely recognized in the literature [13]. Aromatic hydrocarbons affect lymphatic, hematopoietic, hepatic, renal and nervous systems [14,15]. In addition, they cause acute effects on skin and mucous membranes [10]. Some occupational hazard studies of workers exposed to high levels of benzene have shown that this pollutant may cause leukemia and cancer of the bone marrow. Other epidemiological studies show an increase of leukemia due to chronic exposure to benzene [16].

Despite VOCs playing an important role in the tropospheric chemistry and potentially causing serious effects on human health, in Mexico there is no national standard that controls VOC concentrations in ambient air for the protection of human health. Some studies have reported levels and sources of VOCs in some important cities in Mexico [7,17-24], but most of them are focused on central regions of Mexico and there is not enough information about atmospheric concentrations of VOCs in developed cities located in the south of the country.

The most important city located to the southeast of Mexico is Merida within of Yucatan State, located in the Peninsula of the same name. In 2010, this city had a population of 777,615 inhabitants, becoming the largest center of population in southeastern Mexico. Merida is the neuralgic center of the metropolitan area constituted by five municipalities with a population of 957,883 inhabitants. This study focuses on the measurement of BTEX concentrations (benzene, toluene, ethylbenzene, xylenes) and criteria air pollutants $\left(\mathrm{O}_{3}, \mathrm{NO}, \mathrm{NO}_{2}, \mathrm{SO}_{2}, \mathrm{CO}\right.$ and $\left.\mathrm{PM}_{2.5}\right)$ in ambient air of two urban sites located in Merida, Yucatan during four seasons in 2016. The main objectives of this research were as follows: (1) to correlate BTEX concentrations with meteorological parameters and criteria air pollutants by bivariate and multivariate analysis (Principal Component Analysis) in order to infer their sources; and (2) to carry out a health risk assessment in order to determine values for the integrated lifetime cancer risk, non-cancer risk, and long-term exposure in order to know the risk to health for Merida inhabitants represented by the existing levels of benzene. 


\section{Methods}

\subsection{Study Site Description}

The municipality of Merida covers $85,841 \mathrm{~km}^{2}$ and is located in the northwestern zone of the state of Yucatan. This territory has a maximum altitude of $9 \mathrm{~m}$ a.s.l. [25] and their northern and northwestern zones have a climate classified as semi-dry and warm, respectively. The rest of the territory has a warm sub-humid climate with rains occurring in summer, with an average annual temperature of $26^{\circ} \mathrm{C}$, and an average annual precipitation of $1000 \mathrm{~mm}$ [25].

This study considered two urban sites located within the Merida Metropolitan Area. One of them located in the center of the municipality of Merida (named SEDUMA) is in a zone with important economic, commercial, cultural and touristic activity, within the facilities of the Urban Development and Environment Secretary of the State of Yucatan. The other site is located in Cholul (one of 133 counties of the Merida Metropolitan Area with 5161 inhabitants), close to hospitals, shopping malls, universities and educational centers in a highly frequented area. Figure 1 shows the specific location of both sampling sites.

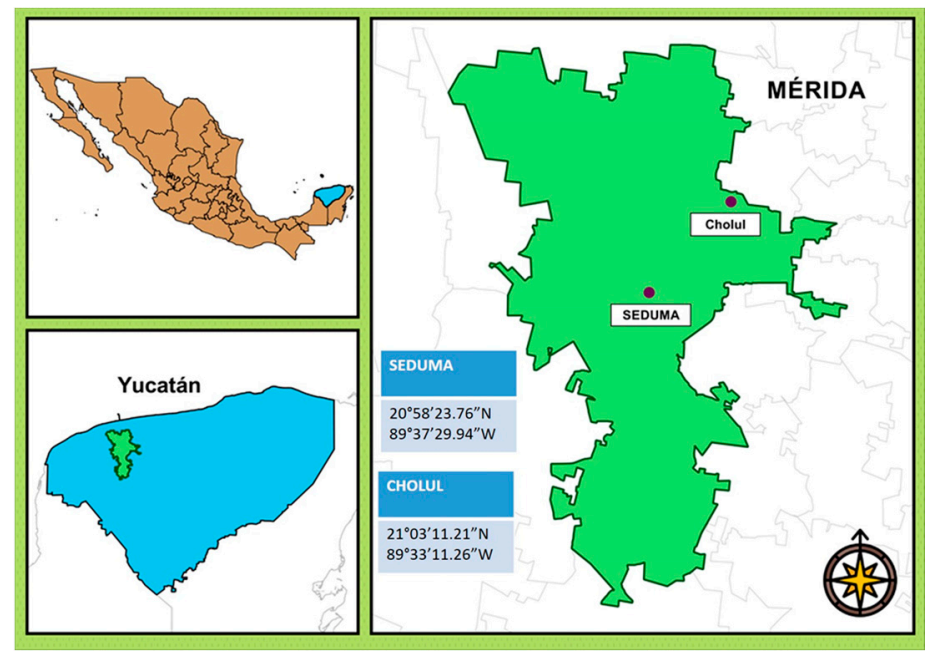

Figure 1. Sampling sites' location.

\subsection{Sampling and Analytical Method}

A total of 192 samples were collected over a period of 12 months (considering spring, summer, autumn and winter seasons) from 12 April 2016 to 13 January 2017. BTEX (benzene, toluene, ethylbenzene and $p$-xylene) were measured in ambient air. Controlled flow of air $\left(200 \mathrm{~mL} \mathrm{~min}^{-1}\right)$ was passed through glass tubes containing active carbon (226-01 Anasorb CSC) using a portable pump model PCXR4 [26]. 1 Samples of $1.5 \mathrm{~h}$ were collected during the morning (SP1: 08:00 to 09:30 h), midday (SP2: 14:00 to 15:30 h) and afternoon periods (SP3: 17:30 to 19:00 h). Samples were labeled, capped tightly with caps and refrigerated until chemical analysis, before being extracted with $1 \mathrm{~mL}$ of $\mathrm{CS}_{2}$ and analyzed using a gas chromatograph (TRACE GC Ultra Thermo Fisher Scientific Technologies, Inc., Waltham, MA, USA) and a flame ionization detector (Thermo Fisher Scientific Technologies, Inc., Waltham, MA, USA) according to the MTA/MA030/A92 Method [26]. Analytical method conditions were as follows: (1) Analytical column: capillary column ( $57 \mathrm{~m}, 0.32 \mathrm{~mm}$, i.e., $0.25 \mu \mathrm{m}$ film thickness); (2) Oven temperature program: $40^{\circ} \mathrm{C}$ for $4 \mathrm{~min}$, then temperature was increased at a rate of $5{ }^{\circ} \mathrm{C} / \mathrm{min}$ up to $100^{\circ} \mathrm{C}$ and maintained for $10 \mathrm{~min}$; (3) Carrier gas: ultra-pure nitrogen $\left(99.999 \%\right.$ ) at $1 \mathrm{~mL} \mathrm{~min}^{-1}$; and (4) Detector: flame ionization (FID) using ultra-pure hydrogen and extra-dried air at $35 \mathrm{~mL} \mathrm{~min}^{-1}$

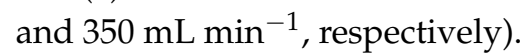


Table 1 shows the method detection limits (MDL), accuracy, exactness and linearity for the analytical method to determine BTEX by GC-FID.

Table 1. Method detection limits (MDL), accuracy, exactness and linearity results for the analytical method.

\begin{tabular}{|c|c|c|c|c|}
\hline Parameter & Benzene & Toluene & Ethylbenzene & $p$-Xylene \\
\hline $\operatorname{MDL}(\mu \mathrm{g} / \mathrm{mL})$ & 0.05 & 0.06 & 0.06 & 0.05 \\
\hline$\%$ RSD & 8.04 & 7.38 & 9.76 & 9.25 \\
\hline \multicolumn{5}{|c|}{ Accuracy and Exactness $(0.1-100 \mu \mathrm{g} / \mathrm{mL})$} \\
\hline average & 1.03 & 1.01 & 1.05 & 1.10 \\
\hline$\%$ RSD & 3.20 & 8.10 & 6.70 & 5.30 \\
\hline$\%$ average error & 2.50 & 5.20 & 2.10 & 4.70 \\
\hline \multicolumn{5}{|c|}{ Linearity $(0.1-100 \mu \mathrm{g} / \mathrm{mL})$} \\
\hline$R^{2}$ & 0.9998 & 0.9952 & 0.9999 & 0.9988 \\
\hline
\end{tabular}

Seven-point calibration $(0.10,1.00,5.00,10.00,20.00,50.00$ and $100.00 \mu \mathrm{g} / \mathrm{mL})$ was performed using $99.98 \%$ Sigma Aldrich analytical reagents for each BTEX and R square values reported in Table 1. Method detection limits (MDLs) for each compound were calculated by multiplying the standard deviation obtained from seven replicate measurements of the first level of calibration $(0.10 \mu \mathrm{g} / \mathrm{mL})$ by $1.943 \mathrm{t}$-Student for $n=7$ (t-Student distribution for $n-1$ with a confidence of $95 \%$ ). Relative standard deviation (\% RSD) were calculated for each compound. Accuracy of the method was estimated through repeatability of seven replicas of BTEX solution in the range of 0.10 to $100.00 \mu \mathrm{g} / \mathrm{mL}$, and the averages are reported in Table 1 for each measured BTEX. According to Table 1, these detection limits are acceptable as long as coefficient variations were lower than 10\% for all measured BTEX. Accuracy and exactness were assessed in a concentration range of 1 to $50 \mu \mathrm{g} / \mathrm{mL}$. The acceptance criterion for accuracy is that variation coefficient should be lower than $10 \%$. This criterion was fulfilled in all measured BTEX. The acceptance criterion for exactness was also fulfilled in all compounds. According to the results (Table 1), it can be observed that the analytical method is accurate and exact in the assessed range of concentration. The linearity $\left(R^{2}\right)$ of the analyzed range can be accepted if $R^{2}$ values $>0.995$, since $p$-value in the ANOVA is less than 0.001 , indicating that the analysis complies the linearity patterns.

\subsection{Measurements of Criteria Air Pollutants and Meteorological Parameters}

Meteorological parameters (wind speed and direction, relative humidity, temperature, solar radiation and barometric pressure) were also measured from 12 April 2016 to 13 January 2017 using Davis Vantage Pro II portable meteorological stations. Details about resolution, operation range and accuracy of the meteorological station instruments are shown in the Supplementary Material Section. Wind roses were constructed using the software WRPLOT (from Lakes Environmental) [27] for each day during the studied period. $\mathrm{O}_{3}, \mathrm{NO}_{2}, \mathrm{CO}, \mathrm{PM}_{2.5}$ and $\mathrm{SO}_{2}$ were measured using Thermo Scientific automatic analyzers (Table 2 shows general details for the measurement instruments). These data were obtained for Cholul sampling site from a mobile air quality multi-pollutant station and for SEDUMA sampling site from an air quality station of the Integrated Air Quality Monitoring System of the Merida Metropolitan Area located in the center of the city within the facilities of the Urban Development and Environment Secretary of the State of Yucatan. 
Table 2. Air quality stations characteristics, measured air criteria pollutants and details of the instruments.

\begin{tabular}{|c|c|c|}
\hline Criteria Air Pollutant & Instrument Details (SEDUMA Site) & Instrument Details (Cholul Site) \\
\hline Ozone $\left(\mathrm{O}_{3}\right)$ & $\begin{array}{l}\text { UV Photometric } \mathrm{O}_{3} \text { analyzer model } 49 \mathrm{i} \text {; } \\
\text { Thermo Fisher } \mathrm{Scientific} \text { Inc., Waltham, } \\
\text { MA, USA , 50-1000 ppb; lower detectable } \\
\text { limit: } 1 \text { ppb; sample flow rate: } 1-3 \mathrm{LPM} \text {. }\end{array}$ & $\begin{array}{l}\text { UV absorption } \mathrm{O}_{3} \text { analyzer; Teledyne, } \\
\text { model T400; range: } 0-20,000 \mathrm{ppb} \text {; lower } \\
\text { detectable limit }<0.4 \mathrm{ppb} \text {; sample flow rate: } \\
800 \mathrm{cc} / \mathrm{min}+10 \% \text {. }\end{array}$ \\
\hline Sulfur dioxide $\left(\mathrm{SO}_{2}\right)$ & $\begin{array}{l}\text { Pulsed fluorescence } \mathrm{SO}_{2} \text { analyzer model } \\
43 \mathrm{i} \text {; Thermo Fisher } \mathrm{Scientific} \mathrm{Inc.,} \mathrm{custom} \\
\text { range: } 0-0.05 \text { to } 100 \mathrm{ppm} \text {; lower } \\
\text { detectable limit }<0.5 \mathrm{ppb} \text {; sample flow } \\
\text { rate: } 0.5 \mathrm{~L} / \mathrm{min} \text { (standard). }\end{array}$ & $\begin{array}{l}\text { UV Fluorescence } \mathrm{SO}_{2} \text { analyzer; Teledyne, } \\
\text { model T100; range: } 0-20,000 \mathrm{ppb} \text {; lower } \\
\text { detectable limit: } 0.4 \mathrm{ppb} \text {; sample flow rate: } \\
650 \mathrm{cc} / \mathrm{min}+10 \% \text {. }\end{array}$ \\
\hline $\begin{array}{l}\text { Carbon monoxide } \\
\text { (CO) }\end{array}$ & $\begin{array}{l}\text { Gas filter correlation CO analyzer } \\
\text { (infrared light); model } 48 \mathrm{i} \text {; Thermo Fisher } \\
\text { Scientific Inc., range: } 0-1 \text { to } 100 \mathrm{ppm} \text {; } \\
\text { flow rate: } 0.5 \text { to } 2 \mathrm{~L} / \mathrm{min} \text {. }\end{array}$ & $\begin{array}{l}\text { Gas filter correlation CO analyzer; Teledyne, } \\
\text { model T-300; range: } 0-1000 \mathrm{ppb} \text {; lower } \\
\text { detectable limit: } 0.04 \mathrm{ppm} \text {; sample flow rate: } \\
800 \mathrm{cc} / \mathrm{min}+10 \% \text {. }\end{array}$ \\
\hline $\begin{array}{l}\text { Nitrogen dioxide } \\
\left(\mathrm{NO}_{2}\right)\end{array}$ & 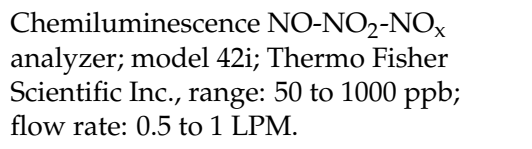 & $\begin{array}{l}\text { Chemiluminescence } \mathrm{NO} / \mathrm{NO}_{2} / \mathrm{NO}_{\mathrm{x}} \\
\text { analyzer; Teledyne; range: } 0-20,000 \mathrm{ppb} \text {; } \\
\text { lower detectable limit }<0.4 \mathrm{ppb} \text {; sample } \\
\text { flow rate: } 500 \mathrm{cc} / \mathrm{min}+10 \% \text {. }\end{array}$ \\
\hline $\begin{array}{l}\text { Particulate matter } \\
\left(\mathrm{PM}_{2.5}\right)\end{array}$ & $\begin{array}{l}\text { Continuous ambient particulate monitor } \\
\text { (beta monitor); model 5014i; Thermo } \\
\text { Fisher Scientific Inc., range: } \\
0-5000 \mu \mathrm{g} / \mathrm{m}^{3} \text {; minimum detection limit: } \\
<4 \mu \mathrm{g} / \mathrm{m}^{3}\left(1 \mathrm{~h} \text { ) and }<1 \mu \mathrm{g} / \mathrm{m}^{3}(24-\mathrm{h}) ;\right. \\
\text { nominal flow rate: } 16.67 \mathrm{~L} / \mathrm{min}\end{array}$ & $\begin{array}{l}\text { Particulate monitor, Teledyne API, model } \\
\text { T640 PM Mass Monitor; range: } \\
0-10,000 \mu \mathrm{g} / \mathrm{m}^{3} \text {; lower detectable limit: } \\
<0.1 \mu \mathrm{g} / \mathrm{m}^{3}(1 \mathrm{~h}) \text {; sample flow rate: } 5 \mathrm{LPM} \text {. }\end{array}$ \\
\hline
\end{tabular}

\subsection{Statistical Analysis}

Data were analyzed using XLSTAT software version 2017.1 [28]. The non-parametric Friedman's test $(\alpha=0.05)$ was used to evaluate differences among seasons and among sampling periods (morning, midday and afternoon) of the measured air pollutant concentrations. Pearson's correlation was used to identify relations among BTEX and criteria air pollutants and meteorological variables. A Principal Component Analysis (PCA) was used for explaining the variance and for uncovering the structure of the data set. This method has been broadly used in environmental studies in order to identify patterns in data [29-31]. A PCA analysis creates new variables (principal component scores: PCs) which are linear combinations of the original variables. Thus the first PC accounts for the maximum of the total variance, the second is uncorrelated with the first and accounts for the maximum of the residual variance, and so on. The results of PCA are resumed as scores and loading vectors usually represented in biplots or factor load tables reveal connections between observations. The information revealed from PCA is useful to identify, for example, if a pollutant is secondary or primary, or to identify the specific source of the pollutants.

\subsection{Health Risk Assessment}

Health risks (cancer and non-cancer) associated with measured benzene by inhalation was determined according to the methodology described by Zhang and collaborators [32]. Daily exposure (E), the hazard quotient for non-hazard risk (HQ), and integrated lifetime cancer risks (ILTCR) were calculated using the following equations:

$$
\mathrm{E}=(\mathrm{C} \times \mathrm{IRa} \times \mathrm{DA}) / \mathrm{BW},
$$

where $\mathrm{E}$ is daily exposure expressed in $\mathrm{mg} / \mathrm{kg}$ per day of an individual by inhalation, $\mathrm{C}\left(\mathrm{mg} \mathrm{m}^{-3}\right)$ is the concentration of benzene in ambient air, IRa is the inhalation rate for adults $\left(0.83 \mathrm{~m}^{3} \mathrm{~h}^{-1}\right)$ and children $\left(0.87 \mathrm{~m}^{3} \mathrm{~h}^{-1}\right)$ [33], DA is the exposure duration of an adult (24 h/day), and BW is the body weight of an adult $(65 \mathrm{~kg})$ and of a child $(36 \mathrm{~kg})$ [34]. The integrated lifetime risk (ILTCR) is then calculated as follows: 


$$
\mathrm{ILTCR}=\mathrm{E} \times \mathrm{SF},
$$

where $\mathrm{SF}$ is the slope factor $(\mathrm{kg}$ day $/ \mathrm{mg}$ ) of inhalation unit risk for toxics when the exposurecarcinogenic effect is considered linear. The non-cancer risk (HQ quotient) was calculated by dividing the yearly average daily-received concentration (CY) by the inhalation reference concentrations of the specific air pollutant (RfC) [11], where an $\mathrm{HQ}>1$ indicates that long-term exposure may result in adverse health effects:

$$
\mathrm{HQ}=\mathrm{CY} / \mathrm{RfC},
$$

\section{Results}

\subsection{Diurnal and Seasonal Variation of BTEX (Benzene, Toluene, Ethylbenzene and Xylene) in Study Area}

Benzene was the dominant compound at both sites during all four seasons. The relative abundance for both sampling sites were as follows: benzene $>$ toluene $>p$-xylene $>$ ethlybenzene. The lifetime of benzene in the atmosphere is approximately 9.4 days, which is enough to explain the dominant presence of this pollutant in urban areas [35]. On the other hand, the rest of BTEX (toluene, ethylbenzene and $p$-xylene) have very short lifetimes in ambient air (from one hour to a few dozen hours) in urban areas. Even though in Mexico there is a standard that regulates the levels of benzene in fuels, Merida is located in a non-critical region so the quality of gasoline may be different from other priority areas such as Mexico City, and benzene content in gasolines may be up to $3 \%$. This could result in a higher emission of benzene from motor vehicles at the study sites (motorization index in this region is of 505 vehicles/1000 inhabitants). Figures 2 and 3 show seasonal variation for benzene, toluene, ethylbenzene and $p$-xylene, for the Cholul and SEDUMA sites, respectively. In general, the Cholul site presented slightly higher values for all measured BTEX over the SEDUMA site, probably due to the site being located near the most important avenue in Merida (Periférico Manuel Berzunza), which runs all over the city from south to north and from east to west).

The Friedman test was applied to investigate whether there were significant differences in concentrations of BTEX at the different seasons of the year and sampling periods (SP1: morning; SP2: midday; SP3: afternoon). For Cholul (Figure 2), it can be observed that benzene levels were distributed in a uniform way during the day; however, this compound showed a clear seasonal pattern with higher concentrations during summer and spring seasons and lower levels during autumn and winter seasons. Toluene and ethylbenzene showed the same diurnal and seasonal patterns as follows: summer $>$ spring $>$ autumn $>$ winter. $p$-Xylene showed higher levels during spring and summer and lower concentrations during winter season. The results for Cholul did not show statistically significant differences for BTEX levels among the different sampling periods (SP) at a significance level of $\alpha=0.05$. Friedman's test performed on seasons indicated that benzene, ethylbenzene and $p$-xylene levels presented significant differences in the Cholul site.

For the SEDUMA site (Figure 3), all measured BTEX showed higher concentrations for spring and summer and lower levels during autumn and winter. Levels of BTEX were statistically different during all the different sampling periods according to the Friedman's test results for this site. Benzene, toluene and ethylbenzene showed significant differences among the different seasons of the year, whereas $p$-xylene levels did not show significant differences for seasonal analysis. Higher concentrations of BTEX in spring and summer at both sites may be attributed to weather conditions during these seasons (lower wind speed and higher average temperatures) which could result in an increased volatilization of BTEX from regional sources and evaporation from motor vehicles and fuel service stations. During spring and summer, the temperature in this zone can reach up to $40^{\circ} \mathrm{C}$, while during autumn and winter it can decrease up to $19^{\circ} \mathrm{C}$. On the other hand, Merida is one of the most important cities in Mexico, thus seeing an increase in the influx of tourists at the same time as a respective increase in vehicular traffic during these seasons of the year. 
Tables 3 and 4 show diurnal variation of BTEX for both sampling sites (Cholul and SEDUMA). For the Cholul site (Table 3), all measured BTEX had higher concentration values during midday (SP2) and afternoon sampling periods (SP3) in spring and summer seasons. These periods coincide with the occurrence of higher ambient temperatures.

At the SEDUMA site (Table 4), higher levels of benzene were found during midday sampling period (SP2) in summer and autumn, whereas the rest of BTEX showed higher concentrations during morning and afternoon sampling periods (SP1 and SP3). This behavior matches with early morning and evening rush hours.

Table 3. Diurnal variation and descriptive statistical of BTEX for the Cholul site. SP1: morning period (08:00-09:30 h); SP2: midday period (14:00-15:30 h); SP3: afternoon period (17:30-19:00 h).

\begin{tabular}{|c|c|c|c|c|c|c|c|c|c|c|c|c|}
\hline \multicolumn{13}{|c|}{ CHOLUL SITE } \\
\hline \multicolumn{13}{|c|}{ SPRING } \\
\hline \multirow{2}{*}{$\mu \mathrm{g} / \mathrm{m}^{3}$} & \multicolumn{3}{|c|}{ Benzene } & \multicolumn{3}{|c|}{ Toluene } & \multicolumn{3}{|c|}{ Ethylbenzene } & \multicolumn{3}{|c|}{$p$-Xylene } \\
\hline & SP-1 & SP-2 & SP-3 & SP-1 & SP-2 & SP-3 & SP-1 & SP-2 & SP-3 & SP-1 & SP-2 & SP-3 \\
\hline Mean & 53.12 & 52.94 & 50.57 & 7.63 & 3.42 & 7.29 & 8.18 & 6.98 & 10.81 & 25.75 & 17.58 & 26.43 \\
\hline Maximum & 69.32 & 77.36 & 75.87 & 15.48 & 12.63 & 17.69 & 16.96 & 17.7 & 33.34 & 78.98 & 81.29 & 80.96 \\
\hline Minimum & 42.72 & 27.22 & 36.63 & 0.77 & 1.74 & $0.03 *$ & 4.01 & 3.69 & 3.73 & 4.31 & 1.65 & 4.55 \\
\hline Standard Deviation & 8.76 & 17.08 & 12.23 & 5.35 & 4.13 & 7.06 & 4.87 & 4.45 & 10.07 & 25.98 & 24.54 & 27.65 \\
\hline Median & 51.91 & 47.19 & 48.99 & 5.77 & 2.43 & 7.18 & 6.09 & 5.51 & 7.06 & 12.03 & 8.87 & 12.62 \\
\hline \multicolumn{13}{|c|}{ SUMMER } \\
\hline \multirow{2}{*}{$\mu \mathrm{g} / \mathrm{m}^{3}$} & \multicolumn{3}{|c|}{ Benzene } & \multicolumn{3}{|c|}{ Toluene } & \multicolumn{3}{|c|}{ Ethylbenzene } & \multicolumn{3}{|c|}{$p$-Xylene } \\
\hline & SP-1 & SP-2 & SP-3 & SP-1 & SP-2 & SP-3 & SP-1 & SP-2 & SP-3 & SP-1 & SP-2 & SP-3 \\
\hline Mean & 57.67 & 58.64 & 61.10 & 10.87 & 9.04 & 15.06 & 10.22 & 11.62 & 12.74 & 16.57 & 15.90 & 28.30 \\
\hline Maximum & 86.86 & 73.58 & 88.71 & 56.06 & 36.65 & 55.63 & 46.02 & 55.99 & 31.50 & 66.99 & 61.43 & 84.67 \\
\hline Minimum & 44.87 & 44.87 & 42.94 & 0.23 & $0.04 *$ & 1.14 & 4.08 & 4.18 & 3.78 & 4.76 & 4.78 & 3.66 \\
\hline Standard Deviation & 12.27 & 8.93 & 18.14 & 17.73 & 10.90 & 21.24 & 13.60 & 16.79 & 10.71 & 19.82 & 17.53 & 28.82 \\
\hline Median & 54.13 & 59.22 & 52.82 & 3.58 & 6.44 & 3.70 & 4.43 & 5.41 & 6.07 & 6.62 & 9.8 & 10.91 \\
\hline \multicolumn{13}{|c|}{ AUTUMN } \\
\hline \multirow{2}{*}{$\mu \mathrm{g} / \mathrm{m}^{3}$} & \multicolumn{3}{|c|}{ Benzene } & \multicolumn{3}{|c|}{ Toluene } & \multicolumn{3}{|c|}{ Ethylbenzene } & \multicolumn{3}{|c|}{$p$-Xylene } \\
\hline & SP-1 & SP-2 & SP-3 & SP-1 & SP-2 & SP-3 & SP-1 & SP-2 & SP-3 & SP-1 & SP-2 & SP-3 \\
\hline Mean & 26.57 & 24.97 & 22.35 & 7.08 & 7.26 & 6.19 & 2.58 & 2.96 & 2.64 & 7.12 & 8.07 & 8.27 \\
\hline Maximum & 36.25 & 31.66 & 27.63 & 25.30 & 11.84 & 9.87 & 4.40 & 5.06 & 4.65 & 9.71 & 10.24 & 12.50 \\
\hline Minimum & 12.17 & 11.04 & 14.89 & 0.52 & 1.64 & 2.83 & 1.52 & 1.98 & 1.25 & 4.85 & 6.62 & 5.85 \\
\hline Standard Deviation & 7.94 & 6.55 & 4.93 & 8.21 & 3.64 & 2.88 & 1.00 & 0.96 & 0.97 & 2.06 & 1.27 & 2.23 \\
\hline Median & 27.45 & 26.34 & 24.72 & 3.45 & 8.23 & 5.84 & 2.08 & 2.58 & 2.60 & 6.15 & 7.95 & 8.18 \\
\hline \multicolumn{13}{|c|}{ WINTER } \\
\hline \multirow{2}{*}{$\mu \mathrm{g} / \mathrm{m}^{3}$} & \multicolumn{3}{|c|}{ Benzene } & \multicolumn{3}{|c|}{ Toluene } & \multicolumn{3}{|c|}{ Ethylbenzene } & \multicolumn{3}{|c|}{$p$-Xylene } \\
\hline & SP-1 & SP-2 & SP-3 & SP-1 & SP-2 & SP-3 & SP-1 & SP-2 & SP-3 & SP-1 & SP-2 & SP-3 \\
\hline Mean & 25.51 & 28.64 & 28.85 & 3.12 & 3.04 & 2.40 & 1.81 & 1.95 & 2.24 & 4.20 & 4.18 & 4.12 \\
\hline Maximum & 32.88 & 41.35 & 54.21 & 11.74 & 11.07 & 4.89 & 2.31 & 3.17 & 4.34 & 9.20 & 10.41 & 7.33 \\
\hline Minimum & 20.10 & 17.84 & 18.05 & 0.79 & 0.46 & 0.30 & 1.32 & 1.39 & 1.37 & 2.74 & 2.28 & 2.65 \\
\hline Standard Deviation & 4.18 & 7.22 & 11.39 & 3.69 & 3.47 & 1.77 & 0.32 & 0.60 & 0.89 & 2.20 & 2.62 & 1.49 \\
\hline Median & 24.82 & 29.18 & 27.3 & 1.65 & 1.88 & 2.03 & 1.77 & 1.76 & 1.96 & 3.29 & 3.43 & 3.52 \\
\hline
\end{tabular}


Table 4. Diurnal variation and descriptive statistical of BTEX for the SEDUMA site. SP1: morning period (08:00-09:30 h); SP2: midday period (14:00-15:30 h); SP3: afternoon period (17:30-19:00 h).

\begin{tabular}{|c|c|c|c|c|c|c|c|c|c|c|c|c|}
\hline \multicolumn{13}{|c|}{ SEDUMA SITE } \\
\hline \multicolumn{13}{|c|}{ SPRING } \\
\hline \multirow{2}{*}{$\mu \mathrm{g} / \mathrm{m}^{3}$} & \multicolumn{3}{|c|}{ Benzene } & \multicolumn{3}{|c|}{ Toluene } & \multicolumn{3}{|c|}{ Ethylbenzene } & \multicolumn{3}{|c|}{$p$-Xylene } \\
\hline & SP-1 & SP-2 & SP-3 & SP-1 & SP-2 & SP-3 & SP-1 & SP-2 & SP-3 & SP-1 & SP-2 & SP-3 \\
\hline Mean & 43.48 & 48.65 & 41.37 & 5.36 & 5.18 & 5.49 & 6.52 & 6.39 & 6.32 & 11.71 & 12.30 & 13.23 \\
\hline Maximum & 58.85 & 70.74 & 55.03 & 9.85 & 15.75 & 11.66 & 9.61 & 7.94 & 7.84 & 18.13 & 17.54 & 16.87 \\
\hline Minimum & 31.78 & 38.10 & 25.05 & 0.92 & 0.08 & $0.01 *$ & 5.17 & 4.66 & 4.85 & 7.96 & 7.46 & 10.12 \\
\hline Standard Deviation & 9.26 & 9.45 & 10.40 & 2.74 & 4.41 & 3.53 & 1.41 & 0.98 & 0.93 & 3.02 & 2.78 & 2.33 \\
\hline Median & 42.3 & 46.42 & 43.55 & 5.31 & 4.82 & 5.41 & 5.85 & 6.53 & 6.43 & 10.45 & 12.29 & 13.10 \\
\hline \multicolumn{13}{|c|}{ SUMMER } \\
\hline \multirow{2}{*}{$\mu \mathrm{g} / \mathrm{m}^{3}$} & \multicolumn{3}{|c|}{ Benzene } & \multicolumn{3}{|c|}{ Toluene } & \multicolumn{3}{|c|}{ Ethylbenzene } & \multicolumn{3}{|c|}{$p$-Xylene } \\
\hline & SP-1 & SP-2 & SP-3 & SP-1 & SP-2 & SP-3 & SP-1 & SP-2 & SP-3 & SP-1 & SP-2 & SP-3 \\
\hline Mean & 42.38 & 47.03 & 43.80 & 4.64 & 3.11 & 4.47 & 5.77 & 5.25 & 5.70 & 11.38 & 8.89 & 11.14 \\
\hline Maximum & 49.01 & 53.18 & 51.83 & 12.28 & 8.79 & 14.90 & 11.70 & 8.64 & 8.49 & 27.54 & 18.57 & 24.10 \\
\hline Minimum & 35.88 & 36.50 & 33.30 & 0.30 & 0.34 & 0.86 & 4.19 & 4.03 & 3.83 & 4.22 & 4.63 & 4.90 \\
\hline Standard Deviation & 3.92 & 5.11 & 5.26 & 4.19 & 2.81 & 4.71 & 2.34 & 1.50 & 1.61 & 7.13 & 4.50 & 6.46 \\
\hline Median & 42.68 & 48.72 & 44.82 & 4.22 & 2.16 & 2.41 & 4.97 & 4.48 & 5.3 & 9.75 & 6.85 & 8.41 \\
\hline \multicolumn{13}{|c|}{ AUTUMN } \\
\hline \multirow{2}{*}{$\mu \mathrm{g} / \mathrm{m}^{3}$} & \multicolumn{3}{|c|}{ Benzene } & \multicolumn{3}{|c|}{ Toluene } & \multicolumn{3}{|c|}{ Ethylbenzene } & \multicolumn{3}{|c|}{$p$-Xylene } \\
\hline & SP-1 & SP-2 & SP-3 & SP-1 & SP-2 & SP-3 & SP-1 & SP-2 & SP-3 & SP-1 & SP-2 & SP-3 \\
\hline Mean & 20.97 & 21.52 & 21.43 & 1.68 & 1.22 & 1.83 & 3.15 & 2.52 & 3.65 & 6.50 & 2.19 & 7.22 \\
\hline Maximum & 26.03 & 24.65 & 25.28 & 4.05 & 5.02 & 4.75 & 8.67 & 3.59 & 11.25 & 44.10 & 6.10 & 40.33 \\
\hline Minimum & 15.04 & 14.73 & 18.54 & 0.11 & $0.04 *$ & 0.14 & 2.03 & 1.99 & 1.97 & 0.07 & 0.01 & 0.26 \\
\hline Standard Deviation & 3.67 & 3.11 & 2.24 & 1.18 & 1.61 & 1.47 & 2.10 & 0.54 & 2.89 & 14.24 & 2.09 & 12.66 \\
\hline Median & 21.91 & 23.16 & 21.44 & 1.53 & 0.33 & 1.53 & 2.4 & 2.41 & 2.76 & 1.36 & 1.88 & 2.27 \\
\hline \multicolumn{13}{|c|}{ WINTER } \\
\hline \multirow{2}{*}{$\mu \mathrm{g} / \mathrm{m}^{3}$} & \multicolumn{3}{|c|}{ Benzene } & \multicolumn{3}{|c|}{ Toluene } & \multicolumn{3}{|c|}{ Ethylbenzene } & \multicolumn{3}{|c|}{$p$-Xylene } \\
\hline & SP-1 & SP-2 & SP-3 & SP-1 & SP-2 & SP-3 & SP-1 & SP-2 & SP-3 & SP-1 & SP-2 & SP-3 \\
\hline Mean & 21.70 & 22.42 & 19.59 & 2.64 & 1.59 & 1.76 & 2.93 & 2.83 & 2.75 & 4.62 & 5.31 & 5.04 \\
\hline Maximum & 23.12 & 26.47 & 25.49 & 9.22 & 3.69 & 5.11 & 4.73 & 3.90 & 3.76 & 10.78 & 14.96 & 12.93 \\
\hline Minimum & 19.59 & 19.23 & 15.53 & 0.55 & $0.004 *$ & 0.05 & 2.20 & 1.95 & 2.16 & 1.00 & 0.02 & 0.58 \\
\hline Standard Deviation & 1.26 & 2.16 & 2.74 & 2.63 & 1.35 & 1.68 & 0.80 & 0.68 & 0.47 & 3.21 & 4.72 & 4.31 \\
\hline Median & 21.92 & 22.67 & 19.05 & 1.63 & 1.78 & 1.21 & 2.61 & 2.69 & 2.72 & 3.42 & 3.83 & 2.79 \\
\hline
\end{tabular}

For the SEDUMA site, during spring, toluene and ethylbenzene had higher concentrations with winds blowing from NW, while, benzene and $p$-xylene had higher concentration values when wind blew from $\mathrm{E}$ and NE. In summer season, higher concentrations were found when wind blew from NE for ethylbenzene and $p$-xylene, from $\mathrm{N}$ for benzene and from ESE for toluene.

During autumn, all measured BTEX presented higher levels when winds came from ESE excepting for benzene which had higher concentrations when the wind had a SE direction. Higher concentrations were registered in winter when wind blew from $\mathrm{E}$ for ethylbenzene and $p$-xylene, from $\mathrm{NE}$ for toluene and from SE for benzene. Sources located in these directions could influence the BTEX levels at both sites, highlighting the peripheral avenue called "Manuel Berzunza" (which crosses the city from north to south and from east to west), the federal highway 180 to Cancun located at SE, the federal highway 176 to Chicxulub Port located in the NE and an industrial zone located in NW to be possible sources.

Time-series for BTEX and box-plots for criteria air pollutants $\left(\mathrm{O}_{3}, \mathrm{NO}, \mathrm{NO}_{2}, \mathrm{NO}_{\mathrm{x}}\right.$ and $\left.\mathrm{CO}\right)$ are shown in the Supplementary Materials section for both sampling sites. 


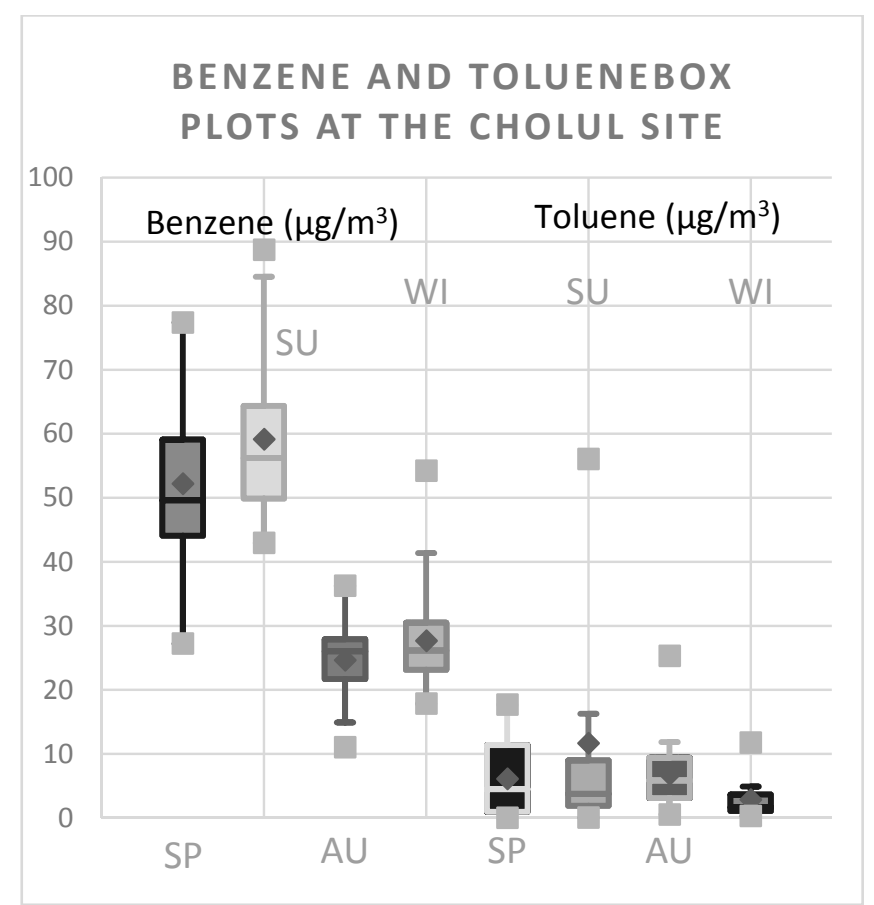

(a)

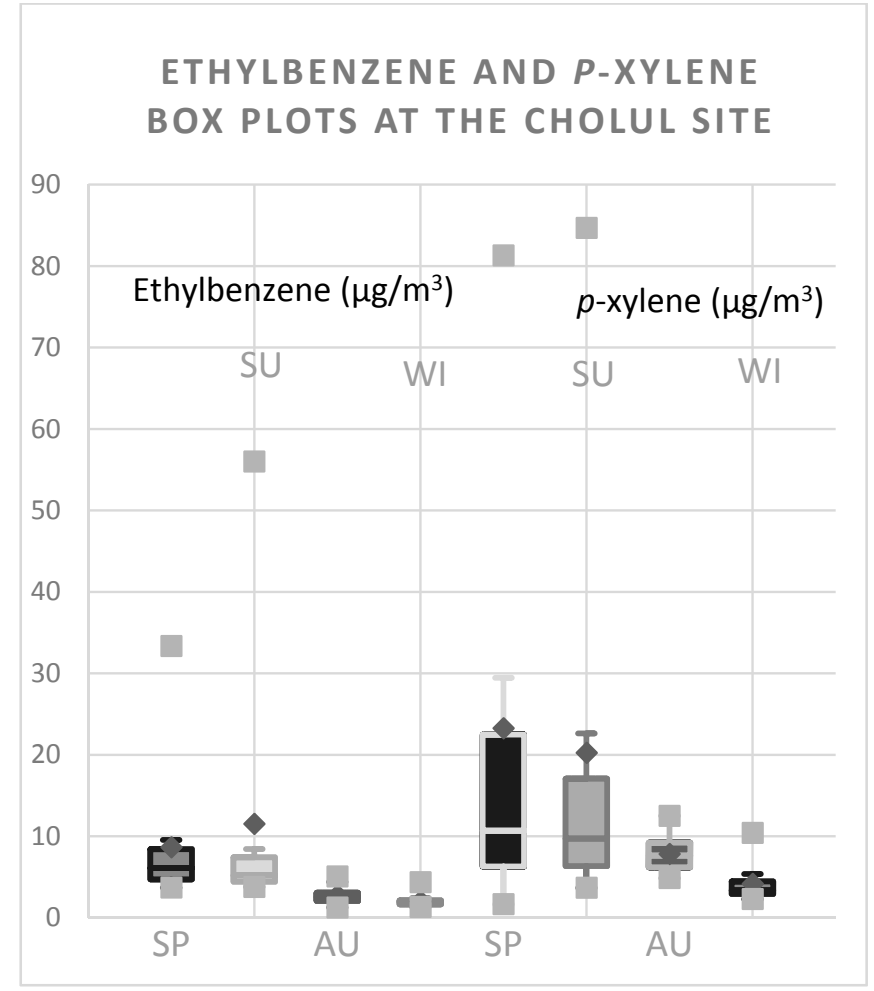

(b)

Figure 2. Seasonal variation and descriptive statistics for BTEX concentrations at the Cholul site. Note: SP: Spring season; SU: Summer season; AU: Autumn season; WI: Winter season. The central horizontal bars are the medians. The lower and upper limits of the box are the first and third quartiles. Where, $\diamond$ is the mean value; $\square$ represents maximum and minimum values; the horizontal width of the box has no statistical significance, and is only for better visualization. (a) box plots for benzene and toluene concentrations at the Cholul site (b) box plots for ethylbenzene and $p$-xylene concentrations at the Cholul site. 


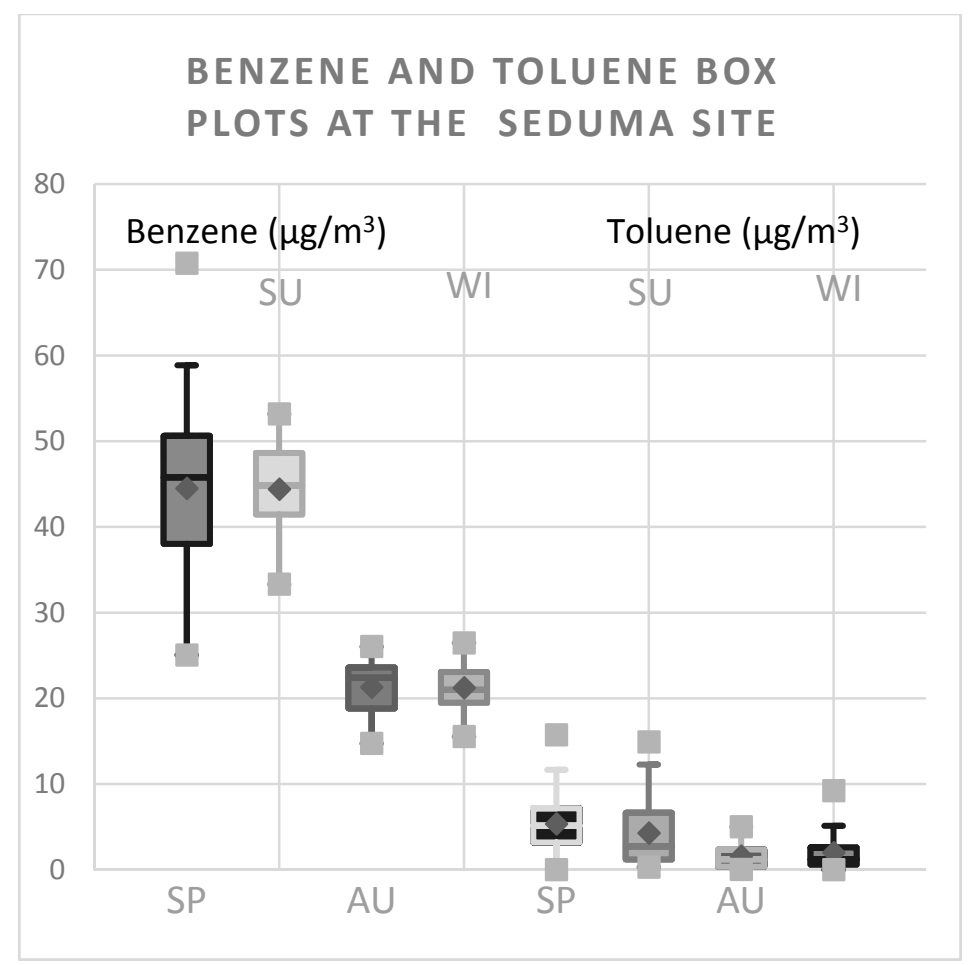

(a)

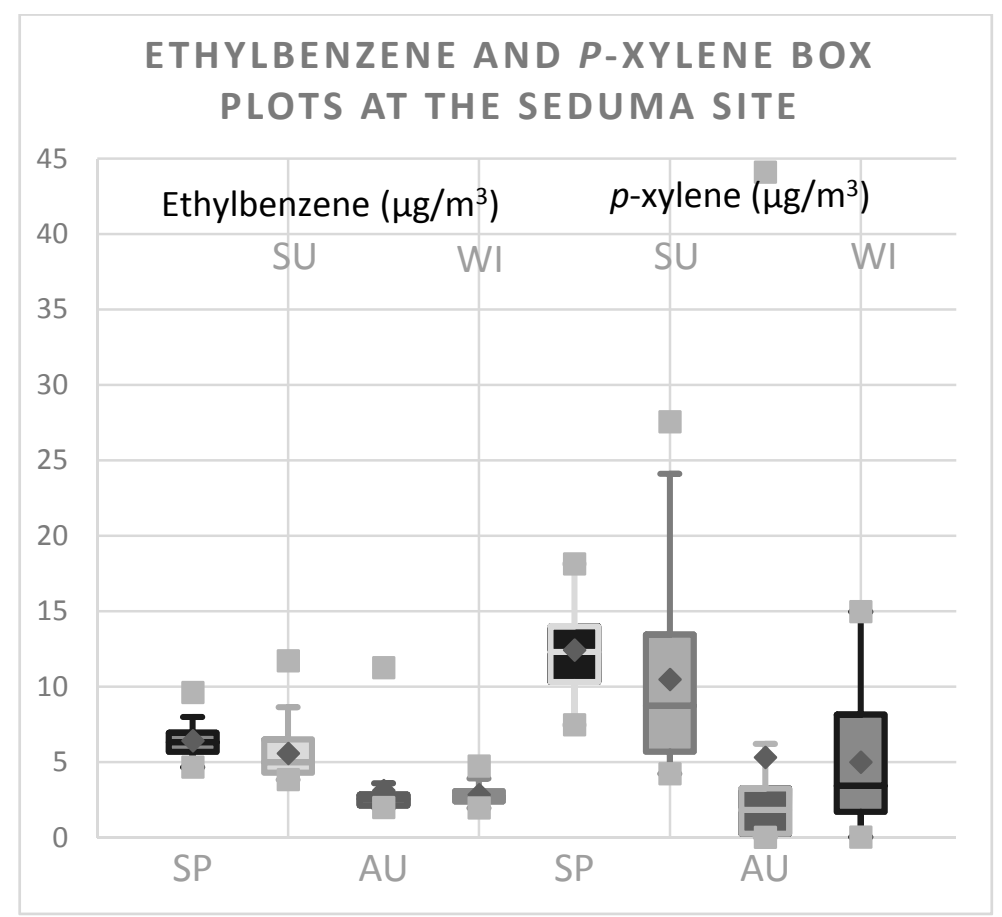

(b)

Figure 3. Seasonal variation and descriptive statistics for BTEX concentrations at the SEDUMA site. Note: SP: Spring season; SU: Summer season; AU: Autumn season; WI: Winter season. The central horizontal bars are the medians. The lower and upper limits of the box are the first and third quartiles. Where $\diamond$ is the mean value; $\square$ represents maximum and minimum values; the horizontal width of the box has no statistical significance and is only for better visualization. (a) box plots for benzene and toluene concentrations at the SEDUMA site $(\mathbf{b})$ box plots for ethylbenzene and $p$-xylene concentrations at the SEDUMA site. 


\subsection{BTEX and Meteorological Conditions}

Solar radiation presented the highest monthly averages in summer and spring (Table 5). Rainfall is frequent by late summer and early fall. Average rainfall during 2016 was 20, 320, 240 and $90 \mathrm{~mm}$ for spring, summer, autumn and winter, respectively. Annual behaviour for temperature, radiation and relative humidity is shown in Table 5. Wind speed and wind direction were similar for both sampling sites. Wind conditions occurring during spring were the following: winds blowing from N, NNE, NE, E, SSE and WNW (frequencies: 3.1\%, 3.1\%, 3.1\%, 5\%, 3.1\% and 3.1\%, respectively), with an average wind speed of $0.5 \mathrm{~ms}^{-1}$ and $79.5 \%$ for calm periods (when no motion of air is detected, the wind is reported as a calm period). During the summer season, winds come from NNW, N, NNE, ESE, $\mathrm{NE}$ and $\mathrm{E}$ (with frequencies of $5 \%, 3 \%, 3 \%, 3.3 \%, 7.6 \%$ and $7.6 \%$, respectively) with an average wind speed of $0.8 \mathrm{~ms}^{-1}$ and calm periods occurring with a frequency of $70.5 \%$. Autumn season presented winds coming from N, NNE, NE, E, ESE and NW with frequencies of $35 \%, 23 \%, 22 \%, 12 \%, 4 \%$ and $4 \%$, respectively, with an average wind speed of $4.3 \mathrm{~ms}^{-1}$ and $0 \%$ for calm periods. During winter, winds came from N, NE, ENE, WSW, NNW, SE and E, with frequencies of $26 \%, 22 \%, 15 \%, 4 \%, 14 \%, 4 \%$ and $13 \%$, respectively, with an average wind speed of $5.6 \mathrm{~ms}^{-1}$ and $0 \%$ for calm periods. Higher ambient temperatures coupled with calm periods and low rainfall during spring and summer months could cause higher BTEX emissions at both study sites compared to the autumn and winter months. Figure 4 shows the typical wind roses for each season for the study area.

Table 5. Meteorological parameters (ambient temperature, relative humidity and solar radiation) for the study area during the whole study period.

\begin{tabular}{cccccccccc}
\hline & \multicolumn{3}{c}{ Temperature $\left({ }^{\circ} \mathbf{C}\right)$} & \multicolumn{3}{c}{ Relative Humidity $(\%)$} & \multicolumn{3}{c}{ Solar Radiation $\left(\mathrm{W} / \mathrm{m}^{2}\right)^{*}$} \\
\cline { 2 - 9 } & Avge & Max & Min & Avge & Max & Min & Avge & Max & Min \\
\hline Spring & 29.5 & 36.4 & 23.9 & 57.1 & 81.7 & 27.4 & 305.6 & 811.4 & 37.2 \\
Summer & 29.6 & 35.4 & 25.4 & 66.7 & 87.4 & 39.9 & 332.8 & 796.8 & 14.6 \\
Autumn & 25.7 & 30.7 & 22.6 & 76.1 & 89.9 & 48.7 & 228.4 & 578.6 & 5.2 \\
Winter & 22.8 & 27.1 & 19.9 & 65.0 & 80.5 & 43.5 & 220.1 & 540.5 & 7.9 \\
\hline
\end{tabular}

Avge: Average value; Max: Maximum value; Min: Minimum value; * Only daytime values were considered for solar radiation based on ae threshold value of $1 \mathrm{~W} / \mathrm{m}^{2}$.

(a) Spring

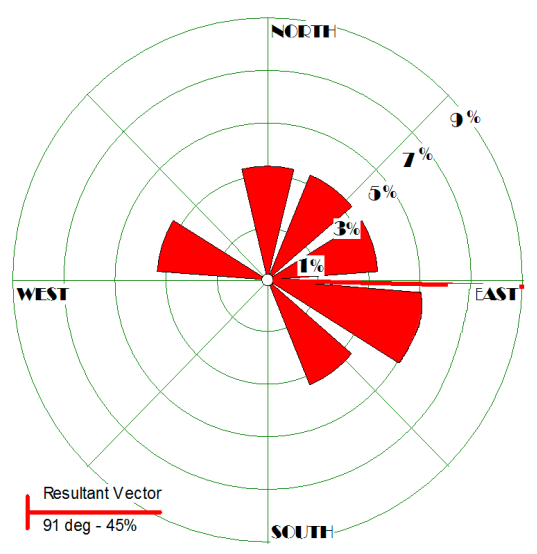

(b) Summer
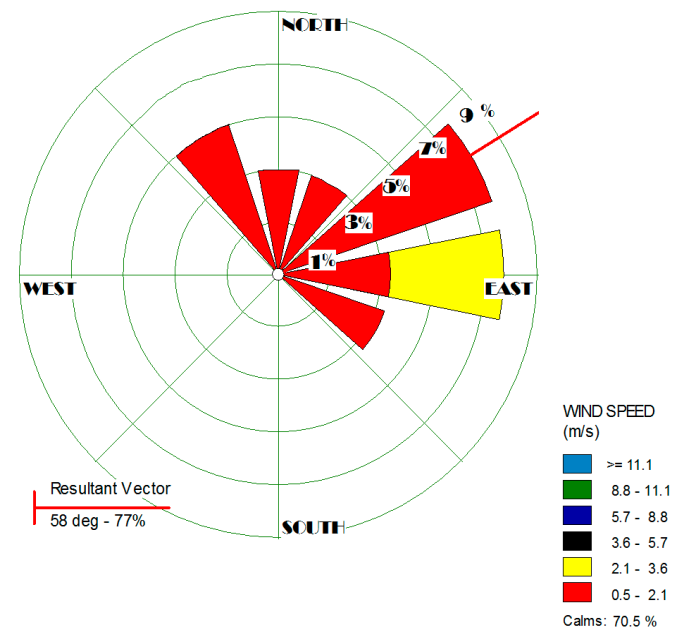

Figure 4. Cont. 
(c) Autumn

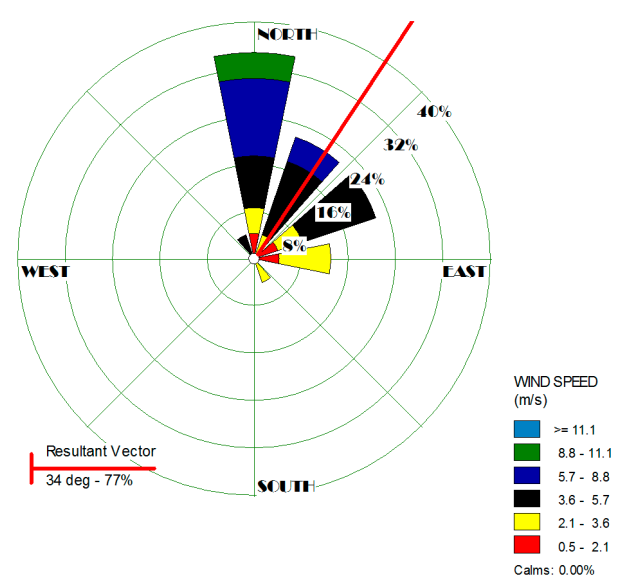

(d) Winter

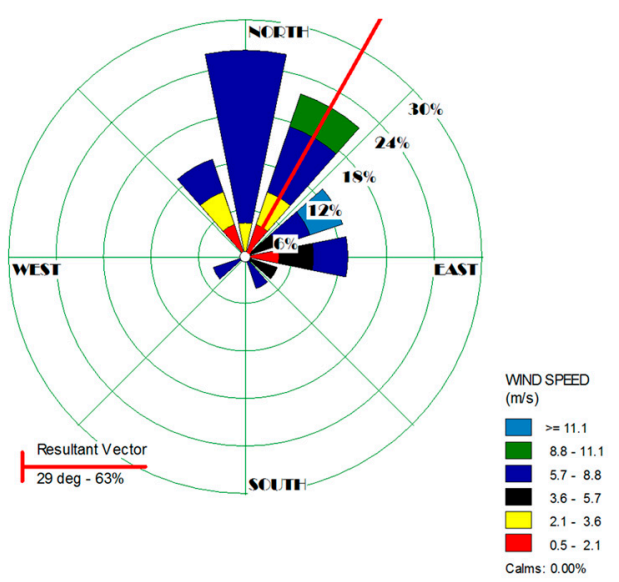

Figure 4. Seasonal wind roses for the study area. (a) wind rose for spring season (b) wind rose for summer season (c) wind rose for autumn season (d) wind rose for winter season.

Even though it would be expected during the spring and summer months (characterized by high solar radiation intensities) that BTEX concentrations would decrease due to photochemical degradation, during these months, low wind speed occurred (being unfavorable for their dispersion) causing an increase of their concentrations. Figure 5 shows variations of BTEX (median concentrations) at both sampling sites with respect to wind direction (wind direction diagrams).

\section{Cholul Site}

(a) Spring

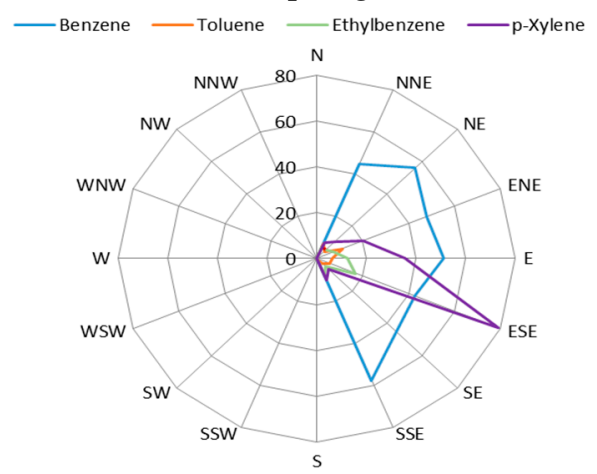

(c) Autumn

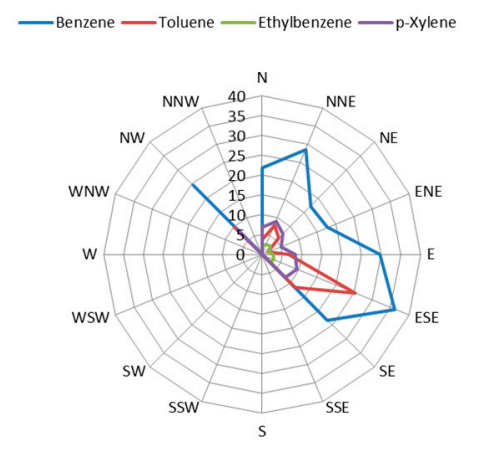

(b) Summer

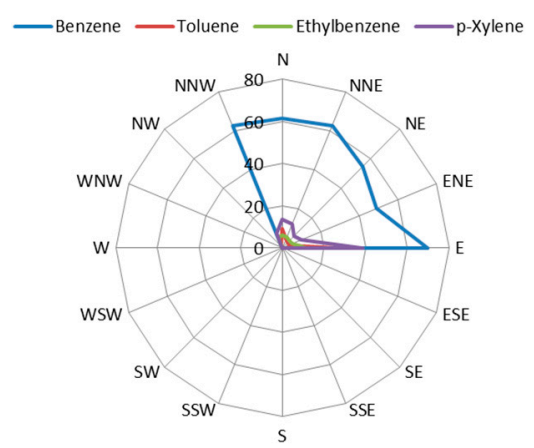

(d) Winter

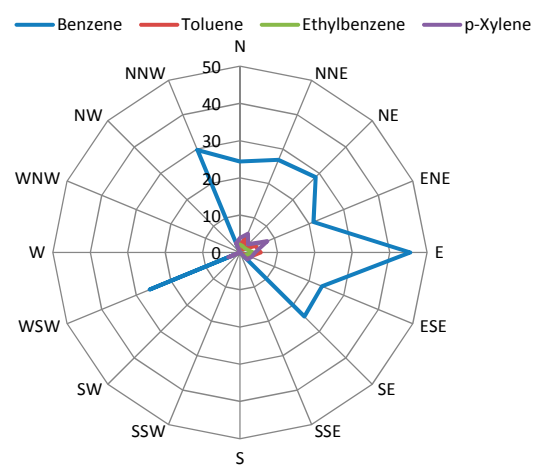

Figure 5. Cont. 


\section{SEDUMA Site}

(e) Spring

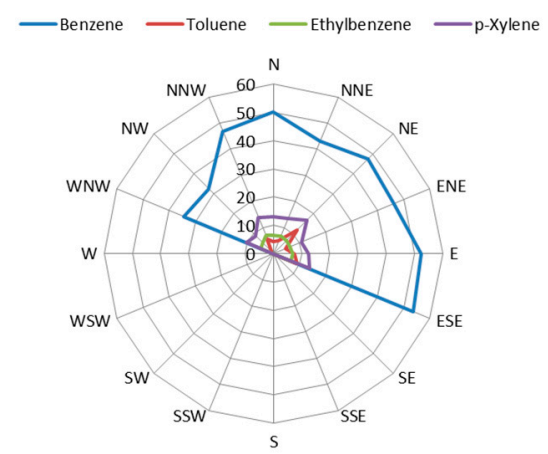

(g) Autumn

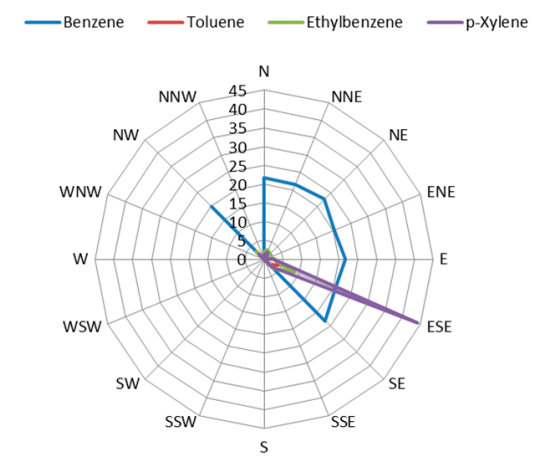

(f) Summer

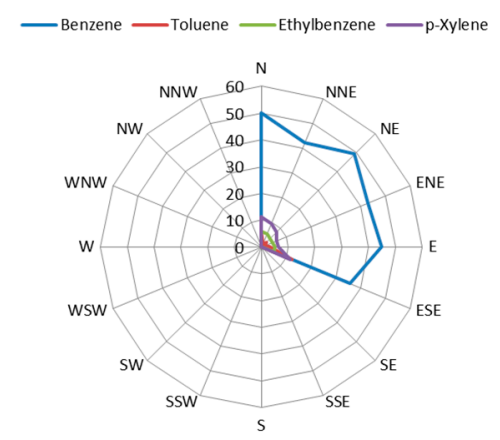

(h) Winter

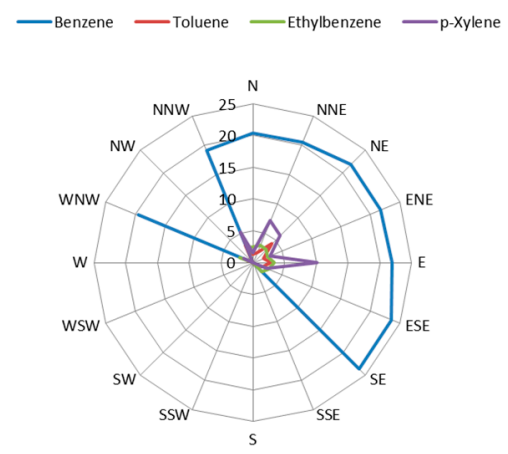

Figure 5. Median concentrations $\left(\mu \mathrm{g} \mathrm{m}^{-3}\right)$ for BTEX and wind direction diagrams for both sampling sites. (a) results for spring season at the Cholul site (b) results for summer season at the Cholul site (c) results for autumn season at the Cholul site (d) results for winter season at the Cholul site (e) results for spring season at the SEDUMA site (f) results for summer season at the SEDUMA site (g) results for autumn season at the SEDUMA site (h) results for winter season at the SEDUMA site.

For the Cholul site during the spring season, ethylbenzene and $p$-xylene had higher median concentrations when winds came from ESE, whereas benzene and toluene showed higher levels (medians) when winds blew from NE and ENE, respectively (Figure 5). During summer and winter, all BTEX probably had common sources since all of them showed higher median concentrations when wind blew from E, except for $p$-xylene in winter, which presented higher levels (medians) when wind came from ENE (Figure 5). During autumn, benzene, toluene and $p$-xylene had higher values of concentration (medians) when the wind had an ESE direction (except for ethylbenzene, which showed higher levels with winds coming from N) (Figure 5).

\subsection{BTEX Correlations, Ratios and Principal Component Analysis Results}

BTEX concentration ratios are commonly used to infer emission sources and to get information about the photochemical processing of air masses [36]. BTEX ratios for both sampling sites are shown in Table 6. 
Table 6. Average BTEX ratios (toluene/benzene and p-xylene/ethylbenzene) at both sites during the whole study period. SP1: morning period (08:00-09:30 h); SP2: midday period (14:00-15:30 h); SP3: afternoon period (17:30-19:00 h).

\begin{tabular}{clccccc}
\hline \multirow{7}{*}{ Teason } & \multicolumn{7}{c}{ Cholul Site } \\
& SP-1 & SP-2 & SP-3 & SP-1 & SP-2 & SP-3 \\
\cline { 2 - 7 } & 0.14 & 0.09 & 0.15 & 2.47 & 1.87 & 2.14 \\
Spring & 0.15 & 0.15 & 0.19 & 1.67 & 1.64 & 1.94 \\
Summer & 0.23 & 0.30 & 0.27 & 2.85 & 2.89 & 3.41 \\
Autumn & 0.12 & 0.10 & 0.09 & 2.49 & 2.27 & 1.93 \\
Winter & \multicolumn{7}{c}{ SEDUMA Site } \\
\hline \multirow{2}{*}{ Season } & Toluene/Benzene Ratio & $p$-Xylene/Ethylbenzene Ratio \\
\cline { 2 - 7 } & SP-1 & SP-2 & SP-3 & SP-1 & SP-2 & SP-3 \\
\hline Spring & 0.12 & 0.09 & 0.13 & 1.79 & 1.92 & 2.09 \\
Summer & 0.11 & 0.07 & 0.10 & 1.85 & 1.61 & 1.81 \\
Autumn & 0.08 & 0.05 & 0.09 & 9.12 & 3.61 & 2.16 \\
Winter & 0.12 & 0.07 & 0.09 & 1.46 & 1.63 & 1.66 \\
\hline
\end{tabular}

Toluene to benzene ratio is used to determine the relative abundance between traffic and non-traffic sources of BTEX. Benzene and toluene are highly correlated with vehicular emissions; however, toluene has other sources such as solvent usage, whereas benzene-due to its toxic nature-is not commonly used in solvent formulations. Therefore, a low toluene/benzene ratio $(<2)$ indicates a strong influence of vehicular emissions on BTEX concentrations at a given site [36-38], while values greater than two may indicate that BTEX levels are associated with sources beyond vehicular traffic such as industrial facilities and regional sources. Average toluene/benzene ratios in this study (Table 6) indicate that the contribution of vehicle sources to measured BTEX levels at both sites was important.

The Cholul site showed significant differences among seasons for this ratio according to the Friedman test, whereas the test of multiple pairwise comparisons using the Nemenyi procedure (bilateral test) showed that the greatest differences were found for the spring-summer pair. In the diurnal analysis, Friedman's test revealed that there were not significant differences among the different sampling periods (SP1: morning; SP2: midday; SP3: afternoon). This ratio did not show significant differences among seasons for the SEDUMA site, though in the diurnal analysis there were important differences between SP2 with respect to SP3 and SP1 (according to Nemenyi procedure/bilateral test). The $p$-xylene to ethylbenzene ratio is commonly used as an indicator of the photochemical age of air masses at a given site. Values higher than 3.8 indicate aged air masses and low values indicate that the air masses are fresh (recent emissions) [39]. Table 6 shows the values obtained for the spring, summer, autumn and winter during 2016 for both sampling sites, indicating that most of the air masses at these sites corresponded to fresh emissions, emitted in situ.

During autumn, the SEDUMA site showed high values of this ratio, proving that during this period the influence of aged air masses was important. Therefore, considering the results for toluene/benzene and p-xylene/ethylbenzene ratios, BTEX at both sites were influenced by local and fresh emissions emitted from mobile sources. For Cholul, there were significant differences among seasons for this ratio, the more evident being the pair autumn-winter. Diurnal analysis, however, revealed that there were no important differences among sampling periods (according to the Friedman test). The SEDUMA site did not show significant differences for this ratio in the seasonal analysis (Friedman's test), whereas diurnal analysis showed important differences between SP2 with respect to SP3 and SP1 (according to Nemenyi procedure/bilateral test).

Table 7 shows a comparison of BTEX levels for both sampling sites with those reported in other cities around the world. It is important to note that every city has specific region sources, as well as 
different meteorological conditions, fuel formulations and consuming patterns, among other factors that may reflect spatial and geographic differences of BTEX levels in ambient air. BTEX levels in this study were lower than those reported for Greater Cairo (Ramsis) [36]. Benzene concentrations for both sampling sites were similar to those found in Athens [40] and Hong Kong [40] but lower than those registered in Ankara [3]. Toluene levels in Cholul and SEDUMA (this study) were similar to those reported for Alicante and Castellon [41]. Ethylbenzene showed concentrations similar to those found in Athens [42] and higher than those reported for Hong Kong [40], Monterrey [43] and Ankara [3]. This study showed $p$-xylene concentrations higher than those found in Alicante [41], Castellon [41], Algiers [44] and Ankara [3], but lower than those reported for Greater Cairo [36].

Table 7. BTEX mean concentrations at the study sites and comparison with other urban areas around the world.

\begin{tabular}{|c|c|c|c|c|}
\hline Site & Benzene $\left(\mu \mathrm{g} \mathrm{m}^{-3}\right)$ & Toluene $\left(\mu \mathrm{g} \mathrm{m}^{-3}\right)$ & Ethylbenzene $\left(\mu \mathrm{g} \mathrm{m}^{-3}\right)$ & $p$-Xylene $\left(\mu \mathrm{g} \mathrm{m}^{-3}\right)$ \\
\hline Athens, Greece b & 37.38 & 79.91 & 17.37 & 49.68 \\
\hline Ramsis, Greater Cairo, Egypt ${ }^{d}$ & 87.20 & 213.8 & 43.30 & 140.80 \\
\hline Foshan City, China $\mathrm{e}$ & 11.24 & 28.62 & - & - \\
\hline Bogotá, Colombia ${ }^{f}$ & 14.69 & - & - & - \\
\hline Castellon, Spain h & 1.8 & 3.6 & - & 2.5 \\
\hline Algiers City, Argelia ${ }^{\mathrm{i}}$ & 9.6 & 15.2 & - & 3.2 \\
\hline Cholul, Yucatan, Mexico j & 40.91 & 6.87 & 13.87 & 6.23 \\
\hline Merida, Yucatan, Mexico ${ }^{k}$ & 32.86 & 3.29 & 8.29 & 4.48 \\
\hline
\end{tabular}

${ }^{\text {a }}$ Yurdakul et al. [3]; ${ }^{\mathrm{b}}$ Rappengluck et al. [42]; ${ }^{\mathrm{c}}$ Chen et al. [40]; ${ }^{\mathrm{d}}$ Khoder et al. [36]; ${ }^{\mathrm{e}}$ Tan et al. [45]; ${ }^{\mathrm{f}}$ Franco and Pacheco [46]; ${ }^{\mathrm{g}}$ Menchaca-Torre et al. [43]; ${ }^{\mathrm{h}}$ Galindo et al. [41]; ${ }^{\mathrm{i}}$ Kerbachi et al. [44]; ${ }^{\mathrm{j}, \mathrm{k}}$ the present study.

\section{Pearson Correlation Analysis}

A Pearson correlation analysis was carried out in order to determine bivariate relations among the measured variables. The Pearson correlation results are shown in the section Supplementary Materials for both sampling sites.

During spring, ozone had strong negative correlations with $\mathrm{NO}_{\mathrm{x}}(-0.61 ;-0.54)$ and relative humidity $(-0.63 ;-0.49)$ for Cholul and SEDUMA sites, respectively. Ozone concentrations were affected by moisture content through washout processes acting as a natural scrubber and brought down ozone levels in the atmosphere. $\mathrm{O}_{3}$ showed a strong correlation with $p$-xylene in the Cholul site $(-0.48)$. Negative correlations between $\mathrm{O}_{3}-\mathrm{NO}_{x}$ and $\mathrm{O}_{3}-p$-xylene indicate that these pollutants could act as ozone precursors during springtime; this was expected, since $p$-xylene has a high potential for ozone formation, being more reactive than the rest of the aromatic hydrocarbons. It is well known that tropospheric ozone is formed in the presence of sunlight by the precursors involving $\mathrm{NO}_{\mathrm{x}}, \mathrm{CH}_{4}$, $\mathrm{CO}$, and VOCs. VOCs and $\mathrm{CO}$ react with $\mathrm{NO}$ in the presence of sunlight to form $\mathrm{NO}_{2}$, which is photolyzed to produce $\mathrm{O}_{3}$. Ethylbenzene and $p$-xylene had strong positive correlations at both sites $(0.85 ; 0.83)$ indicating that these aromatic hydrocarbons could have originated from common sources. BTEX did not correlate with CO, thereby indicating likely origins in sources beyond vehicular traffic, probably regional sources (smaller facilities, such as commercial fuel combustion sources, residential fuel combustion, surface coating operations, degreasing and commercial dry cleaning, auto body painting, solvent storage and transport, among others). Toluene concentrations were affected by wind direction (moderate negative correlations: $-0.41 ; 0.44$ ), indicating that local transport of air masses had influence on the levels of this pollutant at both sampling sites. $\mathrm{CO}$ had significant negative correlations with solar radiation $(0.41 ;-0.47)$, indicating that photochemical activity was important at these sites through oxidation reactions of $\mathrm{CO}$ with $\mathrm{OH}$ radicals. About $75 \%$ of $\mathrm{OH}$ radicals react with $\mathrm{CO}$ in urban atmospheres located in tropics where $\mathrm{OH}$ concentrations are higher compared to those found in other latitudes $[47,48]$. Benzene did not correlate with any measured variables at the Cholul site but it had 
significant correlations with toluene (0.64), ethylbenzene (0.47), $p$-xylene (0.52) and temperature (0.41) at the SEDUMA site, indicating that high temperatures at this site promoted the volatilization of BTEX in ambient air likely as a result of service stations and solvent storage.

Pearson's correlation coefficients during summer revealed that $\mathrm{CO}$ correlated in a significant way with $\mathrm{NO}_{\mathrm{x}}(0.88)$ and $\mathrm{O}_{3}(-0.55)$ at both sampling sites, thus indicating that in the presence of large concentrations of nitric oxide, the oxidation of $\mathrm{CO}$ leads to formation of tropospheric ozone. Solar radiation was strongly correlated with temperature (0.68), whereas $\mathrm{NO}_{\mathrm{x}}-\mathrm{O}_{3}$ showed a correlation coefficient of -0.71 , evidencing that this pollutant acted as $\mathrm{O}_{3}$ precursor and that photochemical activity was important at both sites. SEDUMA during summer was influenced by vehicular traffic showing significant correlations between CO-toluene (0.43) and toluene- $\mathrm{NO}_{\mathrm{x}}(0.49)$, indicating that these pollutants probably had their origin in combustion sources. Cholul showed significant correlations among $\mathrm{PM}_{2.5}$ and benzene (0.76), toluene (0.60), ethylbenzene (0.41), and $p$-xylene (0.55), suggesting that BTEX at this site could contribute to secondary organic aerosol (SOA) formation. All measured BTEX showed strong relations among each other indicating that all these VOCs could have originated from common sources (See Supplementary Material). The effect of wind speed (WS) on $\mathrm{PM}_{2.5}(0.67)$ in Cholul was more evident than that on gaseous pollutants during this period.

All measured BTEX at both sampling sites during autumn season showed significant positive correlation between each other, indicating that they originated from common sources (see Supplementary Material section). $\mathrm{CO}$ had strong negative correlations with $\mathrm{O}_{3}(-0.73)$ and temperature $(-0.63)$, indicating that this pollutant was probably oxidized by $\mathrm{OH}$ radicals to form tropospheric ozone. Ozone and temperature correlated in a positive significant way (0.44). This positive correlation could be due to their role in photochemical formation of $\mathrm{O}_{3}$; similar findings have been reported by NRC [47], and by Jacob and Winner [48]. Temperature and solar radiation had negative correlation with relative humidity ( -0.96 and -0.63 , respectively). Temperature-solar radiation had a strong correlation $(0.60)$, indicating that even in autumn, photochemical activity and high temperatures occur frequently in this region.

The Pearson correlation analysis for Cholul during winter showed strong positive correlations between $\mathrm{CO}$ and benzene (0.5), toluene (0.45), ethylbenzene (0.51) and $\mathrm{NO}_{\mathrm{x}}(0.94)$, indicating that all these pollutants had their origin in vehicular traffic emissions and high temperature combustion processes. Ozone showed negative strong correlations with $\mathrm{NO}_{\mathrm{x}}(-0.78)$ and $\mathrm{CO}(-0.85)$ at both sampling sites, indicating that these pollutants acted as ozone precursors during this period. Higher wind speed occurring during winter and coming from the north could influence $\mathrm{CO}, \mathrm{NO}_{\mathrm{x}}$ and toluene levels, decreasing their concentrations at both sites (Pearson correlation coefficients $>0.7$ ). Ozone was removed from the air column by washout processes, since this pollutant showed a significant negative correlation coefficient with relative humidity $(-0.58)$.

A Principal Components Analysis was applied in order to investigate the relations among BTEX and the different measured variables (meteorological parameters and criteria air pollutants).

The factor loads for both sampling sites during spring, summer, autumn and winter are shown in Tables 8-11. For the Cholul site during spring (Table 8), three principal factors were enough to explain $61.05 \%$ of the total variability, and three groups (PCs) were identified: PC1, which includes ozone precursors and pollutants influenced by temperature and relative humidity $\left(\mathrm{CO}, \mathrm{NO}_{\mathrm{x}}, \mathrm{O}_{3}, \mathrm{RH}\right.$ and temperature); $\mathrm{PC} 2$, formed by toluene, wind speed, wind direction and barometric pressure, indicating that toluene was influenced by transport from another sites; and finally PC3, which is composed by benzene, ethylbenzene and $p$-xylene, indicating that these pollutants could have originated from common sources. For the SEDUMA site (Table 8), three principal factors (PCs) were required to explain $72.47 \%$ of the total variance. PC1 included all measured BTEX (benzene, toluene, ethylbenzene and $p$-xylene), PC2 included $\mathrm{NO}_{\mathrm{x}}$ and meteorological parameters (wind speed, relative humidity, temperature and barometric pressure) and $\mathrm{PC} 3$ provided evidence for the importance of photochemical activity in the removal of $\mathrm{CO}$ from the atmosphere (solar radiation and $\mathrm{CO}$ ). 
Factor loads for the Cholul site during summer are shown in Table 9. Three principal factors were necessary to explain $72.47 \%$ of the total variance and three groups were identified. PC1, which included all measured BTEX, $\mathrm{PM}_{2.5}$ and wind speed (showing the probable participation of BTEX in SOA formation and the importance of transport from other sites); PC2 which included ozone precursors $\left(\mathrm{CO}, \mathrm{NO}_{\mathrm{x}}\right), \mathrm{O}_{3}$, relative humidity, temperature and barometric pressure; and $\mathrm{PC} 3$ comprising $\mathrm{CO}$ and solar radiation. For the SEDUMA site during summer season, factor loads (Table 9) show that three principal components were enough in order to explain $66.12 \%$ of the data variability. Pollutants associated with photochemical activity $\left(\mathrm{CO}, \mathrm{NO}_{\mathrm{x}}, \mathrm{O}_{3}\right)$ and meteorological parameters influencing the levels of these pollutants (relative humidity, temperature and barometric pressure) might be grouped in a first factor; all measured BTEX, excepting benzene can be included in a second factor; whereas, solar radiation and temperature could be included in a third factor.

For the autumn season at the Cholul site, PCA revealed three factors explaining $70.59 \%$ of the total variance (See Table 10). A first factor included meteorological parameters (relative humidity, temperature, barometric pressure and solar radiation); a second factor included pollutants associated with photochemical activity, vehicular traffic and BTEX $\left(\mathrm{CO}, \mathrm{O}_{3}\right.$, benzene, toluene, ethylbenzene and $p$-xylene), and a third factor comprising wind speed and wind direction. For the SEDUMA site during this sampling period, PCA results revealed that three principal components were necessary to explain $65.08 \%$ of the data variability (Table 10). $\mathrm{CO}, \mathrm{O}_{3}$, relative humidity, temperature, barometric pressure and solar radiation could be grouped in a first factor; ethylbenzene, $p$-xylene and wind direction could be included in a second factor; and toluene and wind speed were included in a third factor.

PCA results for the winter season are shown in Table 11. For Cholul, three principal components explained $70.14 \%$ of the total variance within the data set. Factor 1 comprises $\mathrm{CO}, \mathrm{NO}_{\mathrm{x}}, \mathrm{O}_{3}$, benzene, ethylbenzene and wind speed, evidencing the importance of dispersion due to strong winds coming from North; Factor 2, which includes relative humidity, temperature and solar radiation; and Factor 3 including toluene, $p$-xylene and barometric pressure. For the SEDUMA site, $69.58 \%$ of the data variability could be explained by three main components. Factor 1 including $\mathrm{CO}, \mathrm{NO}_{\mathrm{x}}, \mathrm{O}_{3}$, wind speed and relative humidity; Factor 2, which includes temperature, barometric pressure and solar radiation; and Factor 3, including BTEX, except for toluene.

Table 8. Factor loads from the Principal Component Analysis for measured variables for both sampling sites during spring season.

\begin{tabular}{|c|c|c|c|c|c|c|}
\hline \multicolumn{7}{|c|}{ SPRING 2016} \\
\hline \multirow{2}{*}{ Variables } & \multicolumn{3}{|c|}{ Cholul Site } & \multicolumn{3}{|c|}{ SEDUMA Site } \\
\hline & PC1 & PC2 & PC3 & PC1 & PC2 & PC3 \\
\hline $\mathrm{CO}$ & 0.55 & & & & & -0.61 \\
\hline $\mathrm{NO}_{\mathrm{x}}$ & 0.60 & & & & 0.59 & \\
\hline $\mathrm{O}_{3}$ & -0.77 & & & & & \\
\hline \multicolumn{7}{|l|}{$\mathrm{PM}_{2.5}$} \\
\hline $\mathrm{B}$ & & & 0.57 & 0.77 & & \\
\hline $\mathrm{T}$ & & & & 0.85 & & \\
\hline $\mathrm{Ebz}$ & & & 0.79 & 0.85 & & \\
\hline$x$ & & & 0.67 & 0.89 & & \\
\hline WS & & -0.58 & & & 0.52 & \\
\hline WD & & -0.53 & & & & \\
\hline $\mathrm{RH}$ & 0.92 & & & & 0.92 & \\
\hline $\operatorname{Tmp}$ & -0.85 & & & & -0.91 & \\
\hline Prs & & 0.83 & & & 0.59 & \\
\hline SR & & & & & & 0.78 \\
\hline
\end{tabular}

Note: Only statistically significant loadings are showed. B: benzene; T: toluene; Ebz: ethylbenzene; $\mathrm{X}$ : $p$-xylene; WS: wind speed; WD: wind direction; Tmp: temperature; Prs: barometric pressure; RH: relative humidity; SR: solar radiation. 
Table 9. Factor loads from the Principal Component Analysis for measured variables for both sampling sites during summer season.

\begin{tabular}{|c|c|c|c|c|c|c|}
\hline \multicolumn{7}{|c|}{ SUMMER 2016} \\
\hline \multirow{2}{*}{ Variables } & \multicolumn{3}{|c|}{ Cholul Site } & \multicolumn{3}{|c|}{ SEDUMA Site } \\
\hline & PC1 & PC2 & PC3 & PC1 & PC2 & PC3 \\
\hline $\mathrm{CO}$ & & 0.56 & 0.46 & 0.68 & & \\
\hline $\mathrm{NO}_{\mathrm{x}}$ & & 0.76 & & 0.79 & & \\
\hline $\mathrm{O}_{3}$ & & -0.78 & & -0.67 & & \\
\hline $\mathrm{PM}_{2.5}$ & 0.81 & & & & & \\
\hline B & 0.76 & & & & & \\
\hline $\mathrm{T}$ & 0.88 & & & & 0.63 & \\
\hline $\mathrm{Ebz}$ & 0.72 & & & & 0.83 & \\
\hline$X$ & 0.86 & & & & 0.82 & \\
\hline WS & 0.57 & & & & & \\
\hline WD & & & & & & \\
\hline $\mathrm{RH}$ & & 0.65 & & 0.63 & & \\
\hline Tmp & & -0.66 & & -0.63 & & 0.59 \\
\hline Prs & & 0.79 & & 0.69 & & \\
\hline SR & & & 0.75 & & & 0.71 \\
\hline
\end{tabular}

Note: Only statistically significant loadings are showed. B: benzene; T: toluene; Ebz: ethylbenzene; $\mathrm{X}: p$-xylene; WS: wind speed; WD: wind direction; Tmp: temperature; Prs: barometric pressure; RH: relative humidity; SR: solar radiation.

Table 10. Factor loads from the Principal Component Analysis for measured variables for both sampling sites during autumn season.

\begin{tabular}{|c|c|c|c|c|c|c|}
\hline \multicolumn{7}{|c|}{ AUTUMN 2016} \\
\hline \multirow{2}{*}{ Variables } & \multicolumn{3}{|c|}{ Cholul Site } & \multicolumn{3}{|c|}{ SEDUMA Site } \\
\hline & PC1 & PC2 & PC3 & PC1 & PC2 & PC3 \\
\hline $\mathrm{CO}$ & & 0.64 & & 0.69 & & \\
\hline \multicolumn{7}{|l|}{$\mathbf{N O}_{\mathbf{x}}$} \\
\hline $\mathrm{O}_{3}$ & & -0.71 & & -0.58 & & \\
\hline B & & 0.74 & & & & \\
\hline $\mathbf{T}$ & & 0.67 & & & & -0.51 \\
\hline $\mathrm{Ebz}$ & & 0.60 & & & 0.69 & \\
\hline$x$ & & 0.64 & & & 0.67 & \\
\hline WS & & & 0.79 & & & 0.65 \\
\hline WD & & & 0.73 & & 0.56 & \\
\hline $\mathbf{R H}$ & -0.92 & & & 0.95 & & \\
\hline $\operatorname{Tmp}$ & 0.95 & & & -0.92 & & \\
\hline Prs & -0.79 & & & 0.70 & & \\
\hline SR & 0.63 & & & -0.66 & & \\
\hline
\end{tabular}

Note: Only statistically significant loadings are showed. B: benzene; T: toluene; Ebz: ethylbenzene; X: $p$-xylene; WS: wind speed; WD: wind direction; Tmp: temperature; Prs: barometric pressure; RH: relative humidity; SR: solar radiation.

Table 11. Factor loads from the Principal Component Analysis for measured variables for both sampling sites during winter season.

\begin{tabular}{ccccccc}
\hline & \multicolumn{3}{c}{ WINTER 2016 } & & \\
\hline \multirow{3}{*}{ Variables } & \multicolumn{3}{c}{ Cholul Site } & \multicolumn{3}{c}{ SEDUMA Site } \\
\cline { 2 - 7 } & PC1 & PC2 & PC3 & PC1 & PC2 & PC3 \\
\hline CO & 0.97 & & & -0.94 & & \\
NO $_{\mathbf{x}}$ & 0.88 & & & -0.85 & & \\
$\mathbf{O}_{3}$ & -0.81 & & & 0.86 & \\
\hline
\end{tabular}


Table 11. Cont.

\begin{tabular}{ccccccc}
\hline \multicolumn{7}{c}{ WINTER 2016 } \\
\hline \multirow{2}{*}{ Variables } & \multicolumn{3}{c}{ Cholul Site } & \multicolumn{3}{c}{ SEDUMA Site } \\
\cline { 2 - 7 } & PC1 & PC2 & PC3 & PC1 & PC2 & PC3 \\
\hline B & 0.57 & & & & & 0.61 \\
T & & & 0.60 & & & 0.85 \\
Ebz & 0.58 & & & & & 0.79 \\
X & & & 0.64 & & & \\
WS & -0.78 & & & 0.76 & & \\
WD & & & & & & \\
RH & & -0.67 & & -0.72 & 0.80 & \\
Tmp & & 0.81 & & & -0.68 & \\
Prs & & & 0.71 & & 0.65 & \\
SR & & 0.71 & & & \\
\hline
\end{tabular}

Note: Only statistically significant loadings are marked in bold. B: benzene; T: toluene; Ebz: ethylbenzene; X: p-xylene; WS: wind speed; WD: wind direction; Tmp: temperature; Prs: barometric pressure; RH: relative humidity; SR: solar radiation.

\subsection{Health Risk Assessment}

Daily average exposures to benzene ( $\mathrm{mg} / \mathrm{kg}$ per day) were calculated for children and adults for both sampling sites (Table 12). Daily average exposures were higher for children at both sampling sites. The individual non-cancer risk quotients (HQ) for benzene were $>1$, thereby indicating that long-term exposure to benzene could represent a health risk in the study area. The estimated cancer risks (ILTCR values) for adults and children were in the order of $6.855 \times 10^{-4}$ to $1.182 \times 10^{-3}$, which are higher than those values established in the guidelines of US EPA $\left(1 \times 10^{-6}\right)$ [49]. These values of ILTCR exceeded the threshold value established by the World Health Organization $\left(1 \times 10^{-5}\right)$ [50]. Cancer risks can be classified into three categories according to Sexton and collaborators [51]: as definitive risk if ILTCR $>1.0 \times 10^{-4}$, probable risk (if ILTC ranks from $1 \times 10^{-5}$ to $1 \times 10^{-4}$ ) and possible risk (if ILTCR ranks from $1 \times 10^{-5}$ to $1 \times 10^{-6}$ ). According to this classification, populations living in the Metropolitan area of Merida, Yucatan would be at definitive risk of suffering cancer.

Table 12. Benzene toxicity profile, daily average exposure, non-cancer hazard and cancer risk for both sampling sites.

\begin{tabular}{|c|c|c|c|c|}
\hline \multicolumn{5}{|c|}{ Toxicity Profile (US DHHS) [52] } \\
\hline Pollutant & CAS No. & $\operatorname{RfC}^{a}\left(\mathrm{mg} \mathrm{m}^{-3}\right)$ & $\begin{array}{l}\text { Inhalation Cancer Slope } \\
\text { Factor (SF) }\end{array}$ & Carcinogenicity \\
\hline \multicolumn{5}{|c|}{ Estimated Values for Exposure, Associated Non-Cancer hazard, and Cancer Risk } \\
\hline & $\begin{array}{c}\text { Yearly average } \\
\text { concentration }\left(\mathrm{mg} \mathrm{m}^{-3}\right)\end{array}$ & $\begin{array}{l}\text { E: Daily average exposure } \\
\text { (mg/kg per day) }\end{array}$ & HQ & ILTCR \\
\hline & $\begin{array}{l}\text { Cholul site: } \\
4.091 \times 10^{-2}\end{array}$ & $\begin{array}{l}\text { Adult: } 7.42 \times 10^{-5} \\
\text { Children: } 1.4 \times 10^{-4}\end{array}$ & 1.36 & $\begin{array}{l}\text { Adult: } 1.182 \times 10^{-3} \\
\text { Children: } 6.855 \times 10^{-4}\end{array}$ \\
\hline & $\begin{array}{l}\text { SEDUMA site: } \\
3.286 \times 10^{-2}\end{array}$ & $\begin{array}{l}\text { Adult: } 7.42 \times 10^{-5} \\
\text { Children: } 1.4 \times 10^{-4}\end{array}$ & 1.095 & $\begin{array}{l}\text { Adult: } 12.89 \times 10^{-4} \\
\text { Children: } 5.5 \times 10^{-4}\end{array}$ \\
\hline
\end{tabular}

${ }^{a}$ Integrated Risk Information System [34]; ${ }^{\mathrm{b}}$ The Risk Assessment Information System [53]; ${ }^{\mathrm{c}}$ EPA Cancer classification, Group A (human carcinogen) [49].

\section{Conclusions}

Benzene was the dominant compound at both sampling sites. Relative abundance of BTEX aromatic hydrocarbons had the following order: benzene $>$ toluene $>p$-xylene $>$ ethylbenzene in both sampling areas. Mean concentrations of BTEX were $40.91 \mu \mathrm{g} \mathrm{m}^{-3}$ and $32.86 \mu \mathrm{g} \mathrm{m}^{-3}$ for benzene; $6.87 \mu \mathrm{g} \mathrm{m}^{-3}$ and $3.29 \mu \mathrm{g} \mathrm{m}^{-3}$ for toluene; $6.23 \mu \mathrm{g} \mathrm{m}^{-3}$ and $4.48 \mu \mathrm{g} \mathrm{m}^{-3}$ for ethylbenzene; $13.87 \mu \mathrm{g} \mathrm{m}^{-3}$ 
and $8.29 \mu \mathrm{g} \mathrm{m}^{-3}$ for the Cholul and SEDUMA sites, respectively. BTEX levels also showed a diurnal pattern at both sites, with higher concentrations during midday and afternoon sampling periods. All measured BTEX had a clear seasonal variation with higher levels during spring and summer, probably due to lower wind speed values and higher average temperatures resulting in higher volatilization rates from fuel service stations, motor vehicles and regional sources. Sources located at ESE, E, ENE and N influenced BTEX levels in Cholul. Sources of pollution located at NW, NE, N, ESE and SE, however, had influence on BTEX concentrations at the SEDUMA site. Low toluene/benzene and $p$-xylene/ethylbenzene ratios were observed during the study period, indicating that both sites were influenced by local and fresh emissions (vehicular traffic). From the Pearson correlation and principal component analysis, it was possible to confirm that in Cholul during summer, autumn and winter, vehicular traffic was the main source for BTEX, whereas regional sources had a more important impact on BTEX levels during spring. During summer in Cholul, the participation of BTEX in SOA formation was likely important since they showed significant correlations with $\mathrm{PM}_{2.5}$. BTEX sources at the SEDUMA site were related to evaporative emissions, regional sources and vehicular traffic. From relations among $\mathrm{O}_{3}, \mathrm{NO}_{x}$ and $\mathrm{CO}$, it was possible to infer that photochemical activity was important at both sites. This behavior was expected since high average temperatures and solar radiation intensities were registered in spring-summer and even during autumn. Health risk assessment results revealed that exposure to benzene exceeded the value of $1 \times 10^{-6}$ for the integrated lifetime cancer risk. On the other hand, hazard quotient values (HQ) for benzene at both sites exceed unity, so it is possible to conclude that the population of Metropolitan Area of Merida is exposed to a definitive risk of suffering cancer in their lifetime due to inhalation exposure to benzene. Therefore, it is necessary to strengthen existing environmental policies, promote the establishment of a national standard that regulates BTEX levels in ambient air, as well as to improve the quality of fuels, subsequently promoting the usage of alternative energy sources and especially improved control of area source emissions.

Supplementary Materials: The following are available online at www.mdpi.com/2073-4433/8/6/107/s1, Figure S1: Time series for measured BTEX in Cholul site, Figure S2: Time series for measured BTEX in SEDUMA site, Figure S3: Box plots for measured air criteria pollutants $\left(\mathrm{O}_{3}, \mathrm{NO}, \mathrm{NO}_{2}, \mathrm{NO}_{\mathrm{x}}\right.$ and $\left.\mathrm{CO}\right)$ in Cholul site, Figure S4: Box plots for measured air criteria pollutants $\left(\mathrm{O}_{3}, \mathrm{NO}, \mathrm{NO}_{2}, \mathrm{NO}_{\mathrm{x}}\right.$ and $\left.\mathrm{CO}\right)$ in SEDUMA site, Table S1: Pearson correlation matrix for measured variables during spring for (a) Cholul site and (b) SEDUMA site, Table S2: Pearson correlation matrix for measured variables during summer for (a) Cholul site and (b) SEDUMA site, Table S3: Pearson correlation matrix for measured variables during autumn for (a) Cholul site and (b) SEDUMA site, Table S4: Pearson correlation matrix for measured variables during winter for (a) Cholul site and (b) SEDUMA site, Table S5: Details of the meteorological stations used in the study.

Acknowledgments: We appreciate the support provided by The Atmospheric Monitoring System (SIMA) belonging to the Office of Urban Development and the Environment of the Yucatan State (SEDUMA).

Author Contributions: Julia Griselda Ceron Breton and Rosa Maria Ceron Breton designed the experiment, analyzed the data and wrote the paper. María de la Luz Espinosa Fuentes and Evangelina Ramírez Lara carried out the statistical analysis. Cynthia Barceló, Francisco Vivas and Marcela Rangel Marrón conducted the fieldwork. Jorge Alfredo Montero Pacheco, Abril Rodriguez Guzmán and Martha Patricia Uc Chi carried out chemical analysis by GC-FID.

Conflicts of Interest: The authors declare no conflict of interest.

\section{References}

1. World Health Organization (WHO). Air Quality Guidelines for Particulate Matter, Ozone, Nitrogen Dioxide and Sulfur Dioxide; Global Update 2005, Summary of Risk Assessment, WHO/SDE/PHE/OEH/06.02; WHO Press: Copenhagen, Denmark, 2006.

2. Marć, M.; Namieśnik, J.; Zabiegała, B. BTEX concentration levels in urban air in the area of the Tri-City agglomeration (Gdansk, Gdynia, Sopot), Poland. Air Qual. Atmos. Health 2014, 7, 489-504. [CrossRef]

3. Yurdakul, S.; Civan, M.; Tuncel, G. Volatile organic compounds in suburban Ankara atmosphere, Turkey: Sources and variability. Atmos. Res. 2013, 120-121, 298-311. [CrossRef]

4. Sierra, A.; Vanoye, A.Y.; Mendoza, A. Ozone sensitivity to its precursor emissions in Northeastern Mexico for a summer air pollution episode. J. Air Waste Manag. Assoc. 2013, 63, 1221-1233. [CrossRef] [PubMed] 
5. SEMARNAT. National Emissions Inventory 2005-Inventario Nacional de Emisiones 2005 (NEI). Available online: http:/ / sinea.semarnat.gob.mx/sinae.php?process=UkVQT1JURUFET1I=\&categ=1 (accessed on 26 October 2016).

6. Harper, C.C.; Faroon, O.; Mehlman, M.A. Carcinogenic effects of benzene as a major component of gasoline and jet fuels. In Hydrocarbon Contaminated Soils, Volume III; Calabrese, E.J., Kostecki, P.T., Eds.; Lewis Publishers: Atlanta, GA, USA, 1993; Volume III, pp. 215-241.

7. Mendoza, A.; León, M.A.; Caballero, P. Emisiones de compuestos orgánicos volátiles durante arranques en frío de automóviles ligeros (Volatile Organic Compound Emissions from Light-Duty Vehicles During Cold-Starts). Ing. Investig. Tecnol. 2010, 11, 333-347.

8. Jian, L.; Zhong, M.S.; Liang, J.; Yao, J.J.; Xia, T.X.; Fan, Y.L.; Li, J.D.; Tang, Z.Q. Application and benefit evaluation of tiered health risk assessment approach on site contamined by benzene. Huan Jing Ke Xue 2013, 34, 1034-1043.

9. Hogstedt, C.; Lundberg, L. Epidemiology of occupational neurobehavioural hazards. Methodological experiences from organic solvent research. Rev. Epidemiol. Sante Publique 1992, 40, S7-S16. [PubMed]

10. Chen, R.; Semple, S.; Dick, F.; Seaton, A. Nasal, eye and skin irritation in dockyard painters. Occup. Environ. Med. 2001, 58, 542-543. [CrossRef] [PubMed]

11. United States Environmental Protection Agency (US EPA) IRIS. Integrated Risk Information System. Benzene; National Center for Environmental Asessment, Office of Research and Development: Washington, DC, USA, 2013. Available online: http://www.epa.gov/iris/subst/0276.htm (accessed on 15 March 2017).

12. United States Environmental Protection Agency (US EPA). Risk Assessment Guidance for Superfund Volume I: Human Health Evaluation Manual (Part F, Supplemental Guidance for Inhalation Risk Assessment); Final EPA Report (EPA/540/-R-070/002); United States Environmental Protection Agency (US EPA): Washington, DC, USA, 2014. Available online: http:/ / www.epa.gov/oswer/riskassessment/ragsf/index.htm (accessed on 14 March 2017).

13. Glass, D.C.; Gary, C.N.; Jolley, D.J.; Gibbons, C.; Sim, M.R.; Fritschi, L.; Adams, G.G.; Bisby, J.A.Y.; Manuel, R. Leukemia risk associated with low-level benzene exposure. Epidemiology 2013, 14, 569-577. [CrossRef] [PubMed]

14. D'Andrea, M.A.; Singh, O.; Reddy, G.K. Health consequences of involuntary exposure to benzene following a flaring incident at British Petroleum refinery in Texas City. Am. J. Disaster Med. 2013, 8, 169-179. [CrossRef] [PubMed]

15. D'Andrea, M.A.; Reddy, G.K. Health effects of benzene exposure among children following a flaring incident at the British Petroleum refinery in Texas City. Pediatr. Hematol. Oncol. 2014, 31, 1-10. [CrossRef] [PubMed]

16. Schnatter, A.R.; Rosamilia, K.; Wojcik, N.C. Review of the literature on benzene exposure and leukemia subtypes. Chem. Biol. Interact 2005, 153-154, 9-21. [CrossRef] [PubMed]

17. Mugica, V.; Vega, H.; Ruiz, G.; Sanchez, G.; Reyes, E.; Cervantes, A. Photochemical Reactivity and Sources of Individual VOCs in Mexico City. In Air Pollution; Brebbia, C.A., Martin-Duque, J.F., Eds.; WIT Press: Ashurst Lodge, Southampton, UK, 2002; Volume 10, pp. 209-217.

18. Mugica, V.; Ruiz, M.E.; Watson, J.; Chow, J. Volatile Organic Compounds in México City Atmosphere: Levels and Sources Apportionment. Atmósfera 2003, 16, 15-27.

19. Mendoza, A.; Gutiérrez, A.A.; Pardo, E.I. Volatile Organic Compounds in the Downtown Area of Mexicali, Mexico during the spring of 2005: Analysis of Ambient Data and Source-Receptor Modeling. Atmósfera 2008, 22, 95-217.

20. Vega, E.; Sánchez-Reyna, G.; Mora-Perdomo, V.; Iglesias, G.S.; Arriaga, J.L.; Limón-Sánchez, T.; Escalona-Segura, S.; Gonzalez-Avalos, E. Air Quality Assessment in a Highly Industrialized Area of Mexico: Concentrations and Sources of Volatile Organic Compounds. Fuel 2011, 90, 3509-3520. [CrossRef]

21. Zheng, J.; Garzon, J.P.; Huertas, M.E.; Zhang, R.Y.; Levy, M.; Ma, Y.; Huertas, H.I.; Jardon, R.T.; Ruiz, L.G.; Tan, H.B.; et al. Volatile organic compounds in Tijuana during the Cal-Mex 2010 campaign: Measurements and source apportionment. Atmos. Environ. 2013, 70, 521-531. [CrossRef] 
22. Cerón Bretón, J.G.; Cerón Bretón, R.M.; Aguilar Ucán, C.A.; Montalvo Romero, C.; Ramírez Lara, E.; Rustrián Portilla, E.; Houbron, E.P.; Cima Mukul, C.; Anguebes Franseschi, F.; Ramírez Elías, M.A.; et al. Levels of BTEX in ambient air in two urban sites located in the center zone of Orizaba Veracruz, Mexico during autumn 2014 and assessment of the carcinogenic risk levels of benzene. Int. J. Energy Environ. 2015, 9, 90-101.

23. Cerón-Bretón, J.G.; Cerón-Bretón, R.M.; Kahl, J.D.W.; Ramírez-Lara, E.; Guarnaccia, C.; Aguilar-Ucán, C.A.; Montalvo-Romero, C.; López-Chuken, U. Diurnal and seasonal variation of BTEX in the air of Monterrey, Mexico: Preliminary study of sources and photochemical ozone pollution. Air Qual. Atmos. Health 2014, 8, 469-482. [CrossRef]

24. Cerón-Bretón, J.G.; Cerón-Bretón, R.M.; Rangel-Marrón, M.; Carballo-Pat, C.G.; Villarreal-Sanchez, G.X.; Uresti-Gómez, A.Y. Diurnal variation of BTX levels in ambient air of one urban site located at the southwest of Mexico City during two seasons in 2013. Int. J. Energy Environ. 2013, 7, 261-271.

25. INSHT Method MTA/MA-030/A92. Aromatic Hydrocarbons Determination in Air (Benzene, Toluene, Ethylbenzene, p-Xylene, 1,2,4-Trimethyl-Benzene): Adsorption in Activated Carbon/Gas Chromatography Method; INSHT Method MTA/MA-030/A92; Social and Occupational Affairs Office: Madrid, Spain, 1992. Available online: http:/ / www.insht.es/InshtWeb/Contenidos/Documentacion/FichasTecnicas/MetodosAnalisis/ Ficheros/MA/MA_032_A98.pdf (accessed on 15 March 2016).

26. National Institute of Statistics and Geography (INEGI). Altitude and Annual Average Rainfall Maps; Yucatan State Government: Yucatan, Mexico, 2010. Available online: http:/ /www.cuentame.inegi.org.mx/monografias/ informacion/yuc/territorio/clima.aspx?tema=me\&e=31 (accessed on 10 April 2016).

27. Lakes Environmental. WRPLOT View Version 7.0: Wind Rose Plots for Meteorological Data. 2011. Available online: http:/ / www.weblakes.com/products/wrplot/index.html (accessed on 15 January 2017).

28. Statistical Software and Data Analysis Add-on for Excel (XLSTAT). 2016. Available online: https://www. xlstat.com/en/ (accessed on 7 November 2016).

29. Abdul-Wahab, S.A.; Bakheit, C.S.; Al-Alawi, S.M. Principal component and multiple regression analysis in modeling of ground-level ozone and factors affecting its concentrations. Environ. Model. Softw. 2005, 20, 1263-1271. [CrossRef]

30. Guo, H.; Wang, T.; Louie, P.K.K. Source apportionment of ambient non-methane hydrocarbons in Hong Kong: Aplication of a Principal Component Analysis/Absolute Principal Component Scores (PCA/APCS) receptor model. Environ. Pollut. 2004, 129, 489-498. [CrossRef] [PubMed]

31. Einax, J.W.; Zwanziger, H.W.; Greiss, S. Chemometrics in Environmental Analysis; Wiley: New York, NY, USA, 2008; p. 45.

32. Zhang, Z.; Wang, X.; Zhang, Y.; Lü, S.; Huang, Z.; Huang, X.; Wang, X. Ambient air benzene at background sites in China's most developed coastal regions: Exposure levels, source implications and health risks. Sci. Total Environ. 2015, 511, 792-800. [CrossRef] [PubMed]

33. United States Environmental Protection Agency (US EPA). Integrated Risk Information System (IRIS) Carcinogenic Effects of Benzene: An Update (EPA/600/P-97/001F); United States Environmental Protection Agency (US EPA): Washington, DC, USA, 1998. Available online: http://www.epa.gov/iris/supdocs / 0276index.html (accessed on 7 February 2017).

34. United States Environmental Protection Agency (US EPA). Air Risk Assessment Work Plan; Air and Radiation Division, Tristate; United States Environmental Protection Agency (US EPA): Washington, DC, USA, 1997. Available online: https://www.epa.gov/risk/risk-assessment-guidelines (accessed on 14 March 2017).

35. Monod, A.; Sive, B.C.; Avino, P.; Chen, T.; Blake, D.R.; Rowland, F.S. Monoaromatic compounds in ambient air of various cities: A focus on correlations between the xylenes and ethylbenzene. Atmos. Environ. 2001, 35, 135-149. [CrossRef]

36. Khoder, M.I. Ambient levels of volatile organic compounds in the atmosphere of Greater Cairo. Atmos. Environ. 2007, 41, 554-566. [CrossRef]

37. Elbir, T.; Cetin, B.; Cetin, E; Bayram, A.; Odabasi, M. Characterization of volatile organic compounds (VOCs) and their sources in the air of Izmir, Turkey. Environ. Monit. Assess. 2007, 133, 149-160. [CrossRef] [PubMed]

38. Yurdakul, S.; Civan, M.; Kuntasal, O.O.; TunceL, K. Temporal variations of BTX compounds in Bursa/Turkey atmosphere. Int. J. Glob. Warm. 2013, 5, 326-344. [CrossRef]

39. Kuntasal, Ö.O. Organic Composition of Particles and Gases in the Ankara Atmosphere. Ph.D. Thesis, Middle East Technical University (METU), Ankara, Turkey, 2017, unpublished thesis. 
40. Chan, C.Y.; Chan, L.Y.; Wang, X.M.; Liu, Y.M.; Lee, S.C.; Zou, S.C.; Sheng, G.Y.; Fu, J.F. Volatile organic compounds in roadside microenvironments of Metropolitan Hong Kong. Atmos. Environ. 2002, 36, 2039-2047. [CrossRef]

41. Galindo, N.; Varea, M.; Gil-Moltó, J.; Yubero, E. BTX in urban areas of eastern Spain: A focus on time variations and sources. Environ. Sci. Pollut. Res. 2016, 23, 18267-18276. [CrossRef] [PubMed]

42. Rappengluck, B.; Fabian, P.; Kalakobas, P.; Vivas, I.; Ziomas, I. Quasi-continuous measurements of non-methane hydrocarbons (NMHC) in the greater Athens area during Medcaphot-Trace. Atmos. Environ. 1998, 36, 2039-2047. [CrossRef]

43. Menchaca-Torre, H.L.; Mercado-Hernandez, R.; Mendoza-Dominguez, A. Diurnal and seasonal variation of volatile organic compounds in the atmosphere of Monterrey, Mexico. Atmos. Pollut. Res. 2015, 6, 1073-1081. [CrossRef]

44. Kerbachi, R.; Boughedaoui, M.; Bounoua, L.; Keddam, M. Ambient air pollution by aromatic hydrocarbons in Algiers. Atmos. Environ. 2006, 40, 3995-4003. [CrossRef]

45. Tan, J.; Guo, S.; Ma, Y.; He, K.; Yang, F.; Yu, Y.; Wang, J. Characteristics of atmospheric non-methane hydrocarbons in Foshan City, China. Environ. Monit. Assess. 2011, 183, 297-305. [CrossRef] [PubMed]

46. Franco, J.F.; Pacheco, J. Characterization and source identification of VOC species in Bogotá, Colombia. Atmosfera 2015, 28, 1-11. [CrossRef]

47. National Research Council (NRC). Rethinking the Ozone Problem in Urban and Regional Air Pollution; National Academic Press: Washington, DC, USA, 1991; p. 524.

48. Jacob, D.J.; Winner, D.A. Effect of climate change on air quality. Atmos. Environ. 2009, 43, 51-63. [CrossRef]

49. US Environmental Protection Agency (US EPA). Risk Assessment Guidance for Superfund Volume I: Human Health Evaluation Manual (Part F, Supplemental Guidance for Inhalation Risk Assessment); Final EPA Report, EPA/540/-R-070/002; US Environmental Protection Agency (US EPA): Washington, DC, USA, 2009. Available online: https:/ / www.epa.gov/risk/risk-assessment-guidance-superfund-rags-part-f (accessed on 10 April 2017).

50. World Health Organization (WHO). Air quality guidelines for Europe. In WHO Regional Publications. European Series, 2nd ed.; WHO Press: Copenhagen, Denmark, 2000; p. 91. Available online: http:/ /www. euro.who.int/_data/assets/pdf_file/0005/74732/E71922.pdf (accessed on 11 February 2017).

51. Sexton, K.; Linder, S.H.; Marko, D.; Bethel, H.; Lupo, P.J. Comparative assessment of air pollution-related health risks in Houston. Environ. Health Perspect. 2007, 115, 1388-1393. [CrossRef] [PubMed]

52. US Department of Health and Human Services (US DHHS). Public Health Service. In Toxicological Profile for Benzene; Agency for Toxic Substances and Disease Registry: Atlanta, GA, USA, 2007. Available online: https:/ / www.atsdr.cdc.gov / toxprofiles/tp3.pdf (accessed on 15 March 2017).

53. US Environmental Protection Agency (US EPA). Risk Assessment Guidance for Superfund: Volume I, Human Health Evaluation Manual (Part D, Standardized Planning, Reporting, and Review of Superfund Risk Assessments); Interim Final Report, No. EPA/540/1-89/002; Office of Emergency and Remedial Responses: Washington, DC, USA, 1998. Available online: https://rais.ornl.gov/documents/RAGSD_EPA540R97033.pdf (accessed on 15 March 2017).

(C) 2017 by the authors. Licensee MDPI, Basel, Switzerland. This article is an open access article distributed under the terms and conditions of the Creative Commons Attribution (CC BY) license (http://creativecommons.org/licenses/by/4.0/). 